\title{
BACE1 Mediates HIV-Associated and Excitotoxic Neuronal Damage Through an APP-Dependent Mechanism
}

\author{
Anna L. Stern, ${ }^{1}$ Shivesh Ghura, ${ }^{1}$ Patrick J. Gannon, ${ }^{1}$ Cagla Akay-Espinoza, ${ }^{1}$ Jessica M. Phan, ${ }^{1}$ Alan C. Yee, ${ }^{1}$ \\ Robert Vassar, ${ }^{2}$ Benjamin B. Gelman, ${ }^{3}$ Dennis L. Kolson, ${ }^{4}$ and ${ }^{\circledR K e l l y ~ L . ~ J o r d a n-S c i u t t o ~}{ }^{1}$ \\ ${ }^{1}$ Department of Pathology, School of Dental Medicine, University of Pennsylvania, Philadelphia, Pennsylvania 19104, ${ }^{2}$ Department of Cell and Molecular \\ Biology, Feinberg School of Medicine, Northwestern University, Chicago, Illinois 60611, ${ }^{3}$ Department of Pathology, University of Texas Medical Branch, \\ Galveston, Texas 77555, and ${ }^{4}$ Department of Neurology, The Perelman School of Medicine, University of Pennsylvania, Philadelphia, Pennsylvania 19104
}

HIV-associated neurocognitive disorders (HANDs) share common symptoms with Alzheimer's disease (AD), which is characterized by amyloid- $\beta(\mathrm{A} \beta)$ plaques. Plaques are formed by aggregation of $\mathrm{A} \beta$ oligomers, which may be the toxic species in $\mathrm{AD}$ pathogenesis, and oligomers are generated by cleavage of amyloid precursor protein (APP) by $\beta$-site amyloid precursor protein cleaving enzyme 1 (BACE1). BACE1 inhibitors reverse neuronal loss and cognitive decline in animal models of AD. Although studies have also found evidence of altered APP processing in $\mathrm{HIV}^{+}$patients, it is unknown whether increased BACE1 expression or A $\beta$ oligomer production is a common neuropathological feature of HAND. Moreover, it is unknown whether BACE1 or APP is involved in the excitotoxic, NMDAR-dependent component of HIV-associated neurotoxicity in vitro. Herein, we hypothesize that HIV-associated neurotoxicity is mediated by NMDARdependent elevation of BACE1 and subsequent altered processing of APP. Supporting this, we observed elevated levels of BACE1 and A $\beta$ oligomers in CNS of male and female $\mathrm{HIV}^{+}$patients. In a model of HIV-associated neurotoxicity in which rat neurons are treated with supernatants from HIV-infected human monocyte-derived macrophages, we observed NMDAR-dependent elevation of BACE1 protein. NMDA treatment also increased BACE1 and both pharmacological BACE1 inhibition and genetic loss of APP were partially neuroprotective. Moreover, in APP knock-out (APP ${ }^{-I-}$ ) mouse neurons, NMDA-induced toxicity was BACE1 independent, indicating that cytotoxicity of BACE1 is dependent upon APP cleavage. Our findings suggest that increased BACE1 and the resultant A $\beta$ oligomer production may contribute to HIV-associated neuropathogenesis and inhibition of BACE1 could have therapeutic potential in HANDs.

Key words: Alzheimer's disease; APP; BACE1; excitotoxicity; HIV-associated neurocognitive disorders; NMDA

Significance Statement

$\mathrm{HIV}$-associated neurocognitive disorders (HANDs) represent a range of cognitive impairments affecting $\sim 50 \%$ of $\mathrm{HIV}^{+}$individuals. The specific causes of HAND are unknown, but evidence suggests that HIV-infected macrophage infiltration into the brain may cause neuronal damage. Herein, we show that neurons treated with conditioned media from HIV-infected macrophages have increased expression of $\beta$-site amyloid precursor protein cleaving enzyme 1 (BACE1), a protein implicated in Alzheimer's disease pathogenesis. Moreover, inhibition of BACE1 prevented neuronal loss after conditioned media exposure, but had no effect on HIV-associated neurotoxicity in neurons lacking its cleavage target amyloid precursor protein. We also observed increased BACE1 expression in $\mathrm{HIV}^{+}$patient brain tissue, confirming the potential relevance of BACE1 as a therapeutic target in HANDs.

\section{Introduction}

HIV-associated neurocognitive disorders (HANDs), which persist in $15-55 \%$ of $\mathrm{HIV}^{+}$individuals despite viral suppression by

\footnotetext{
Received May 8, 2017; revised March 16, 2018; accepted March 20, 2018.

Author contributions: A.L.S., S.G., P.J.G., C.A.-E., and K.L.J.-S. designed research; A.L.S., S.G., P.J.G., C.A.-E., J.M.P., and A.C.Y. performed research; R.V., B.B.G., and D.L.K. contributed unpublished reagents/analytic tools; A.L.S., S.G., P.J.G., and C.A.-E. analyzed data; A.L.S., S.G., and C.A.-E. wrote the paper.

This work was supported by the National Institutes of Health (Grants R01MH109382, R01MH106967, and R01MH098742 to K.L.J.-S.). We thank Margaret Maronski for help in the preparation of primary rat cortical neuroglial cultures, Ping Lin for technical assistance, and Sarah Ratcliffe for help with statistical analysis.

The authors declare no competing financial interests.
}

antiretroviral therapy (ART), are a constellation of cognitive, behavioral, and motor impairments (Sacktor et al., 2016). HANDs have certain clinical (Sacktor and Robertson, 2014) and pathological (Clifford et al., 2009; Borjabad and Volsky, 2012; Levine et al., 2013; Ortega and Ances, 2014) features in common with Alzheimer's disease $(\mathrm{AD})$ and, in an aging $\mathrm{HIV}^{+}$population

Correspondence should be addressed to Dr. Kelly Jordan-Sciutto, Department of Pathology, School of Dental Medicine, University of Pennsylvania, 240 S. 40th St., Rm. 312 Levy Bldg., Philadelphia, PA 19104-6030. E-mail: jordank@upenn.edu.

DOI:10.1523/JNEUROSCI.1280-17.2018

Copyright $\odot 2018$ the authors $\quad 0270-6474 / 18 / 384288-13 \$ 15.00 / 0$ 
(Valcour, 2013), it is increasingly difficult to distinguish AD from the combined effects of age and HIV (Xu and Ikezu, 2009). Understanding the common pathways involved in neuropathology may improve treatment efficacy in HANDs.

In $\mathrm{AD}$, increased amyloid precursor protein (APP) cleavage by $\beta$-site amyloid precursor protein cleaving enzyme-1 (BACE1) leads to overproduction of amyloid- $\beta(\mathrm{A} \beta$ ) peptides (MacLeod et al., 2015). A $\beta$ peptides can oligomerize and ultimately form extracellular aggregates called plaques (Trojanowski et al., 1995). Importantly, although extracellular plaques are a defining feature of $\mathrm{AD}, \mathrm{A} \beta$ oligomers are more likely to be the neuropathogenic species (Kayed and Lasagna-Reeves, 2013; Sengupta et al., 2016). In HANDs, evidence of a role for amyloid is mixed, but numerous studies (Esiri et al., 1998; Brew et al., 2005; Rempel and Pulliam, 2005; Achim et al., 2009; Clifford et al., 2009) have reported altered APP processing and metabolism, even in patients on effective ART regimens (Green et al., 2005; Soontornniyomkij et al., 2012). Unlike in AD, however, ART-treated HANDs patients do not develop extracellular plaques. Rather, evidence suggests diffuse intracellular accumulation of full-length APP, A $\beta$ monomers, or A $\beta$ oligomeric species (Xu and Ikezu, 2009; Ortega and Ances, 2014). Despite its proposed role in AD neuropathogenesis (Kayed and Lasagna-Reeves, 2013; Sengupta et al., 2016), a lack of antibody specificity and wide variation across study designs have made it difficult thus far to determine whether oligomeric $\mathrm{A} \beta$ specifically is accumulated in HANDs.

BACE1 is elevated in AD brains (Yang et al., 2003; Johnston et al., 2005) and BACE1 inhibition effectively decreases plaque burden and improves cognition in animal models of $\mathrm{AD}$ (Ohno et al., 2004; Singer et al., 2005; Chang et al., 2011). Evidence from in vitro experiments in primary rodent neurons shows that BACE1 activity and localization are also affected by treatment with the HIV proteins transactivator of transcription (tat) and glycoprotein 120 (gp120) (Chen et al., 2013; Kim et al., 2013; Bae et al., 2014). However, it remains unclear what role BACE1 plays in HIV-associated neurotoxicity and neuropathogenesis.

Macrophages sustain productive viral infection in HIV patient brains (Koenig et al., 1986; Petito et al., 1986) and infected macrophages may mediate HIV-associated neurotoxicity by secreting factors that include viral proteins, chemokines, and glutamate (Kaul, 2008). Glutamate release in particular has been linked to neuronal damage and cognitive dysfunction in HIV both in vivo and in vitro (Jiang et al., 2001; Zink et al., 2002). Similarly to AD pathology (Mehta et al., 2013), in vitro evidence suggests that glutamate may cause neuronal damage in HIV through NMDAR-dependent mechanisms of excitotoxicity (Giulian et al., 1990; Chen et al., 2002; O'Donnell et al., 2006). Therefore, we used a previously developed and well characterized in vitro model of HIVassociated neurotoxicity (Chen et al., 2002; O’Donnell et al., 2006) in which cultured rat neurons are exposed to supernatants collected from HIV-infected human monocyte-derived macrophages (HIV/MDMs). In this model, neurotoxic injury induced by HIV/MDM supernatants is entirely dependent on NMDAR activation (Giulian et al., 1990; Jiang et al., 2001; Chen et al., 2002; O'Donnell et al., 2006).

Based on the similarities observed thus far between $\mathrm{AD}$ and HANDs in relation to amyloid metabolism (Ortega and Ances, 2014), we hypothesized that neurotoxicity induced by HIV/MDM supernatants is dependent upon NMDAR-mediated upregulation of BACE1 and a resultant increase in amyloidogenic APP processing. To address the potential clinical relevance of this mechanism, we also hypothesized that $\mathrm{A} \beta$ oligomers and BACE1 protein levels are increased in HANDs patient brains.

\section{Materials and Methods}

Chemicals and reagents. The following antibodies were used in this study: $\beta$-site amyloid precursor protein cleaving enzyme 1 (BACE1; catalog \#5606S RRID:AB_1903900), presenilin 1 (PS1; catalog \#5643S RRID: AB_10706356), and $\beta$-actin (catalog \#3700 also 3700P, 3700S RRID: AB_2242334) (all from Cell Signaling Technology); binding Ig protein (BiP; catalog \#610978 RRID:AB_398291; BD Transduction Laboratories; APP (catalog \#ab32136 RRID:AB_2289606), a disintegrin and metalloproteinase domain-containing protein 10 (ADAM10; catalog \#ab1997 RRID:AB_302747), and microtubule-associated protein 2 (MAP2; catalog \#ab5392 RRID:AB_2138153) (all from Abcam); actin (catalog \#A2066 RRID:AB_476693; Sigma Aldrich); and MAP2 (catalog \#801801 RRID: AB_2564643; BioLegend. The mouse monoclonal antibody against BACE1 (3d5) was developed by Dr. Robert Vassar (Feinberg School of Medicine, Northwestern University, Chicago, IL). The antibody against A $\beta$-oligomers (Nab61) was kindly provided by Dr. Virginia Lee (The Perelman School of Medicine, University of Pennsylvania, Philadelphia, PA). The following chemical reagents were used: DAPI (Citifluor); DMEM, neurobasal medium, and B27 supplement (all from Invitrogen); Bradford protein assay dye, polyvinylidene fluoride (PVDF) membrane, and prestained broad range molecular weight ladder (all from Bio-Rad); Tween 20, Triton X-100, Fast Green FCF, protease inhibitor mixture, bovine serum albumin (BSA), dimethyl sulfoxide (DMSO), and cytosine $\beta$-D-arabinofuranoside hydrochloride (AraC) (all from Sigma Aldrich); poly-L-lysine (Peptides International); normal antibody diluent (NAD; Scytek Laboratories); HBSS, trypsin, and GlutaMAX (all from Thermo Fisher Scientific); Luminata Classico ECL and $\beta$-secretase inhibitor (BSI) II and IV (all from Millipore); and amino-5-phosphonovaleric acid (AP5), 6-cyano-7-nitroquinoxaline-2,3-dione (CNQX), dizocilpine (MK-801), and MRK 560 (MRK) (all from Tocris Bioscience). All HRP-conjugated secondary antibodies were obtained from Thermo Fisher Scientific and all fluorescent dye-conjugated secondary antibodies were obtained from Jackson ImmunoResearch Laboratories.

Preparation of primary rat cortical neuron cultures. Primary rat cortical cultures were prepared from embryonic day 18 Sprague Dawley rat embryos (Charles River Laboratories, RRID:RGD_734476). Brains were isolated and dissected cortices were incubated for $40 \mathrm{~min}$ in DMEM and $0.027 \%$ trypsin as described previously (Wilcox et al., 1994). Cells were then washed in saline, triturated, resuspended in neurobasal medium supplemented with B27, and plated on poly-L-lysine-coated 6-well (9.4 $\mathrm{cm}^{2}$ growth area) or 24-well $\left(1.9 \mathrm{~cm}^{2}\right.$ growth area) plates (USA Scientific) at a concentration of 750,000 cells/ml. After $48 \mathrm{~h}$, cells were treated with $10 \mu \mathrm{M}$ AraC to remove dividing glial cells. Cultures were maintained in neurobasal medium supplemented with $\mathrm{B} 27$ at $37^{\circ} \mathrm{C}$ with $5 \% \mathrm{CO}_{2}$ as described previously (Akay et al., 2011; Gannon et al., 2017). At $10 \mathrm{~d}$ in vitro (DIV), 20\% fresh medium was added. Cells were treated on DIV $14-21$.

Preparation of primary mouse cortical neuroglial cultures (MCCs). Primary mouse cortical cultures were prepared from embryonic day 16-18 C57BL/6 WT or $\mathrm{APP}^{-1-}$ mouse embryos (The Jackson Laboratory, RRID:IMSR_JAX:004133). Brains were isolated and dissected cortices were incubated for $15 \mathrm{~min}$ in HBSS and $0.025 \%$ trypsin. Cells were then washed with saline, triturated, and resuspended in neurobasal medium supplemented with B27 and GlutaMAX before plating on poly-L-lysinecoated 6-well $\left(9.4 \mathrm{~cm}^{2}\right.$ growth area) or 24 -well $\left(1.9 \mathrm{~cm}^{2}\right.$ growth area) plates (USA Scientific) at a concentration of 250,000 cells $/ \mathrm{ml}$. Cells were maintained at $37^{\circ} \mathrm{C}$ in $5 \% \mathrm{CO}_{2}$ as described previously (Akay et al., 2011; Gannon et al., 2017) and treated on DIV 14.

Drug treatments. Cells were treated for the time and dose specified for each experiment with NMDA, AP-5 (dissolved in $\mathrm{H}_{2} \mathrm{O}$ ), MK-801, CNQX, BSI II/IV, or MRK (dissolved in DMSO). Pretreatments with MK-801, AP-5, and CNQX were $1 \mathrm{~h}$ before treatment with HIV/MDM supernatant for 16 or $24 \mathrm{~h}$. Pretreatments with BSI or MRK were $1 \mathrm{~h}$ before $24 \mathrm{~h}$ treatment with HIV/MDM supernatant or NMDA.

HIV/MDM supernatants. Monocytes were isolated from healthy human donors and plated at 400,000 cells/ml density in $1.2 \mathrm{ml}$ of medium per well. Cells differentiated into macrophages over $7 \mathrm{~d}$ before infection with HIV-1 as described previously (Cross et al., 2011). Briefly, macro- 
Table 1. Summary of human cases used for immunofluorescence staining in Figure 1

\begin{tabular}{|c|c|c|c|c|c|c|c|}
\hline $\begin{array}{l}\text { NNTC } \\
\text { ID\# }\end{array}$ & $\begin{array}{l}\text { HIV } \\
\text { status }\end{array}$ & $\begin{array}{l}\text { Neurocognitive } \\
\text { diagnosis }\end{array}$ & Age & Sex & $\begin{array}{l}\text { PMI } \\
\text { (h) }\end{array}$ & $\begin{array}{l}\text { ART } \\
>12 \mathrm{mo}\end{array}$ & $\begin{array}{l}\mathrm{A} \beta \\
\text { Oligo }^{a}\end{array}$ \\
\hline 3009 & - & Normal & 53 & $\mathrm{~F}$ & N/A & - & - \\
\hline 3012 & - & Normal & 50 & M & N/A & - & - \\
\hline 7665 & - & Not Tested & 47 & $\mathrm{~F}$ & 19.18 & - & - \\
\hline 8087 & + & Normal & 50 & M & 18 & + & - \\
\hline 6771 & + & Normal & 46 & M & 2.75 & + & + \\
\hline 6568 & + & HAD & 32 & M & 14 & + & ++ \\
\hline 7680 & + & HAD & 34 & $\mathrm{~F}$ & 5 & + & ++ \\
\hline 8270 & + & MCMD & 49 & M & 67.33 & + & + \\
\hline 8382 & + & MCMD & 37 & M & 11.5 & + & + \\
\hline 6683 & + & MCMD & 31 & M & 8.83 & + & ++ \\
\hline 6050 & + & $H A D$ & 40 & $M$ & N/A & + & + \\
\hline 6040 & + & $H A D$ & 34 & $M$ & N/A & + & ++ \\
\hline 4002 & + & HAD & 35 & $M$ & N/A & + & + \\
\hline
\end{tabular}

${ }^{a}$ Extent of hippocampal A $\beta$ oligomer burden as assessed by Nab61 staining.

N/A, Not available; PMI, postmortem interval.

phages were exposed to $20 \mathrm{ng}$ of p24/well of HIV-1 T-cell-propagated virus (89.6) for $24 \mathrm{~h}$ before virus was removed and cells were rinsed thoroughly with DMEM. Supernatants were then collected every $3 \mathrm{~d}$ and macrophage infection was confirmed by HIV reverse transcriptase (RT) assay. DIV 14-21 rat neuronal cultures were treated with a 1:20 to 1:80 dilution of HIV/MDM supernatant; results presented are those in which dilutions led to $\sim 50 \%$ MAP2 loss after $24 \mathrm{~h}$.

Immunofluorescence. Human tissue samples were prepared and stained as follows: paraffin-embedded tissue sections from the hippocampus of control and $\mathrm{HIV}^{+}$human autopsy cases obtained from the National NeuroAIDS Tissue Consortium (NNTC) were prepared for immunofluorescent staining with minor modifications of previously described protocols (Lindl et al., 2007). The age, neurocognitive status, sex, and postmortem interval of each human specimen was provided by the NNTC (Table 1); the cohort included both males $(n=10)$ and females $(n=3)$. Glass slides containing paraffin-embedded tissue sections (10 $\mu \mathrm{M}$ ) were heated overnight to $55^{\circ} \mathrm{C}$, deparaffinized in Histoclear, and rehydrated in $100 \%, 95 \%, 90 \%$, and $70 \%$ ethanol washes. Tissue was then incubated in $3 \% \mathrm{H}_{2} \mathrm{O}_{2}$ in methanol to inactivate endogenous peroxidase activity. Antigen unmasking was performed with target retrieval solution at $95^{\circ} \mathrm{C}$ for $1 \mathrm{~h}$. Sections were then blocked with $10 \%$ normal goat serum and incubated with primary antibody overnight at $4^{\circ} \mathrm{C}$, followed by secondary antibody incubation at room temperature. Tyramide amplification was used to detect BACE1 and DNA was visualized with DAPI staining. Slides were washed with PBS plus $0.1 \%$ Tween 20 (PBS-T) and mounted in Citifluor AF1 and analyzed by laser confocal microscopy at $600 \times$ on a Radiance 2100 equipped with argon, green $\mathrm{He} / \mathrm{Ne}$, red diode, and blue diode lasers (Bio-Rad). Postacquisition analysis was performed using MetaMorph version 6.0 software (Universal Imaging). Total intensity for MAP2 was determined by the measurement of integrated pixel intensity per $z$-stack image, where integrated pixel intensity is defined as total pixel intensity per image times the area of pixels with positive MAP2 signal. Data were analyzed using GraphPad Prism statistical software (version 5.0; RRID:SCR_002798) and data are expressed as mean \pm SEM. Primary neuronal cultures were prepared and stained as follows. After treatment, cells were rinsed with PBS and fixed with $4 \%$ paraformaldehyde for $20 \mathrm{~min}$. Cells were then rinsed twice in PBS and three times in PBS-T, followed by a 30 min incubation with a blocking/ permeabilization solution containing $0.2 \%$ BSA and $0.1 \%$ Triton-X in PBS. Cells were rinsed three times in PBS-T and incubated with MAP2 primary antibody diluted at 1:4000 in NAD for $2 \mathrm{~h}$ at room temperature. After three washes in PBS-T, cells were incubated with a FITC-conjugated goat anti-mouse secondary antibody diluted at 1:500 in NAD for $30 \mathrm{~min}$ at room temperature. Cells were then imaged using a Keyence BZ-X-700 digital fluorescent microscope affixed with UV, FITC, Cy3, and Cy5 filters. Images captured at $20 \times$ magnification were analyzed with the Keyence BZ-X software to quantify the number of neurons. Specifically, the number of neurons, identified as cells expressing MAP2, was aver-

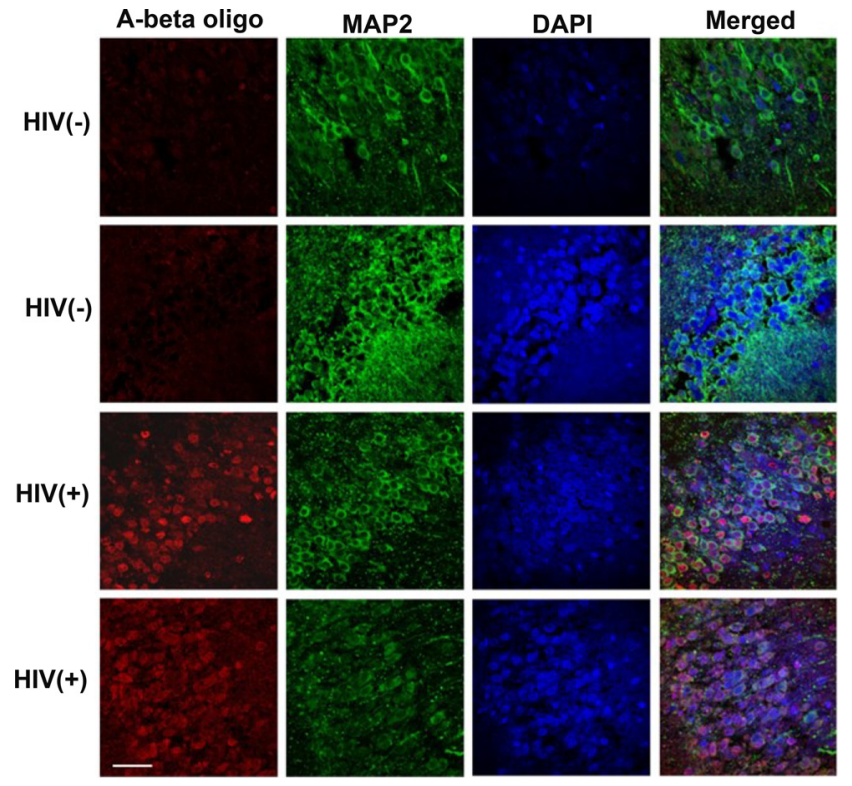

Figure 1. $A \beta$ oligomers are elevated in the brains of $\mathrm{HIV}^{+}$cases. Paraffin-embedded tissue sections from hippocampus of HIV $^{-}$and HIV ${ }^{+}$individuals were prepared for immunofluorescent analysis and visualized by laser confocal microscopy. Representative images are shown from hippocampal sections triple-labeled for A $\beta$ oligomers (red), MAP2 (green), and nuclei (blue). Red and green colocalization appears yellow.

aged across a total of 25 fields/well, with 2-4 wells/treatment condition for each biological replicate.

Immunoblotting. Human tissue was prepared and immunoblotted as follows: flash-frozen whole-brain tissue samples from $\mathrm{HIV}^{-}$control $(n=5)$ and $\mathrm{HIV}^{+}(n=13)$ human autopsy cases for the first cohort and from $\mathrm{HIV}^{-}$control $(n=20)$ and $\mathrm{HIV}^{+}(n=40)$ human autopsy cases for the second cohort were obtained from the tissue banks of the NNTC. Frontal cortex was dissected from Brodmann areas 9 or 10. Tissue was prepared for Western blotting as described previously (Lindl et al., 2007). Briefly, frozen brain tissue $(100 \mathrm{mg})$ was homogenized and solubilized in ice-cold tissue extraction buffer (50 mM Tris pH 7.5, $0.5 \mathrm{~m} \mathrm{NaCl}, 1 \%$ NP-40, 1\% SDS, 2 mм EDTA, 2 mм EGTA, 5 mм NaF, 0.4 mм Na3VO4, $1 \mathrm{~mm}$ DTT and 1:100 protease inhibitor mixture). Extracts were then centrifuged at $12,000 \times g$ at $4^{\circ} \mathrm{C}$ for $20 \mathrm{~min}$. Next, $30 \mu \mathrm{g}$ of protein for each sample was loaded into each lane of $10 \%$ Bis-Tris gels and transferred to PVDF membranes, followed by blocking with Tris-buffered saline plus $0.1 \%$ Tween 20 (TBS-T) with $5 \%$ BSA for $30 \mathrm{~min}$ at room temperature. Membranes were probed with various primary antibodies overnight at $4^{\circ} \mathrm{C}$, followed by secondary antibody incubation at room temperature. Tissue culture samples were prepared and immunoblotted as follows: cells were rinsed twice with PBS and lysed with whole-cell lysis buffer (50 mM Tris pH 7.5, $120 \mathrm{~mm} \mathrm{NaCl}, 0.5 \%$ NP-40, $0.4 \mathrm{~mm} \mathrm{NaF}, 0.4$ $\mathrm{mM} \mathrm{Na}_{3} \mathrm{VO}_{4}$, and $1: 100$ protease inhibitor mixture). Protein supernatants were collected with centrifugation at $20,000 \times g$ for $10 \mathrm{~min}$ at $4^{\circ} \mathrm{C}$. Protein concentrations were determined using the Bradford method and 3-5 $\mu \mathrm{g}$ of total protein per condition was loaded into each lane of precast $10 \%$ Bis-Tris NuPAGE Novex gels (Thermo Fisher Scientific). Proteins were then transferred to PVDF membranes, which were blocked with 5\% BSA in TBS-T for $1 \mathrm{~h}$ at room temperature and incubated overnight with primary antibodies at $4^{\circ} \mathrm{C}$. After three washes in TBS-T, membranes were incubated with HRP-conjugated secondary antibody (1:5000 in 5\% BSA and TBS-T) for $30 \mathrm{~min}$ at room temperature. Bands were visualized by chemiluminescence with Luminata Classico ECL and images were captured by film development or ChemiDoc Touch imaging system (BioRad). Equal loading and even transfer of samples were confirmed using Fast Green staining of the membranes. Densitometric analysis of band intensities was conducted using ImageJ software version 1.44 (RRID: SCR_003070) and all bands were normalized to Fast Green stain.

Rat A $\beta$ ELISAs. Media were collected from NMDA-treated primary rat neurons at several time points. Samples were centrifuged at $4^{\circ} \mathrm{C} 20,000$ 
A

HIV(-)

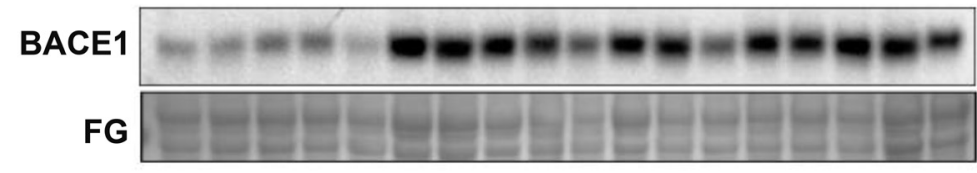

B

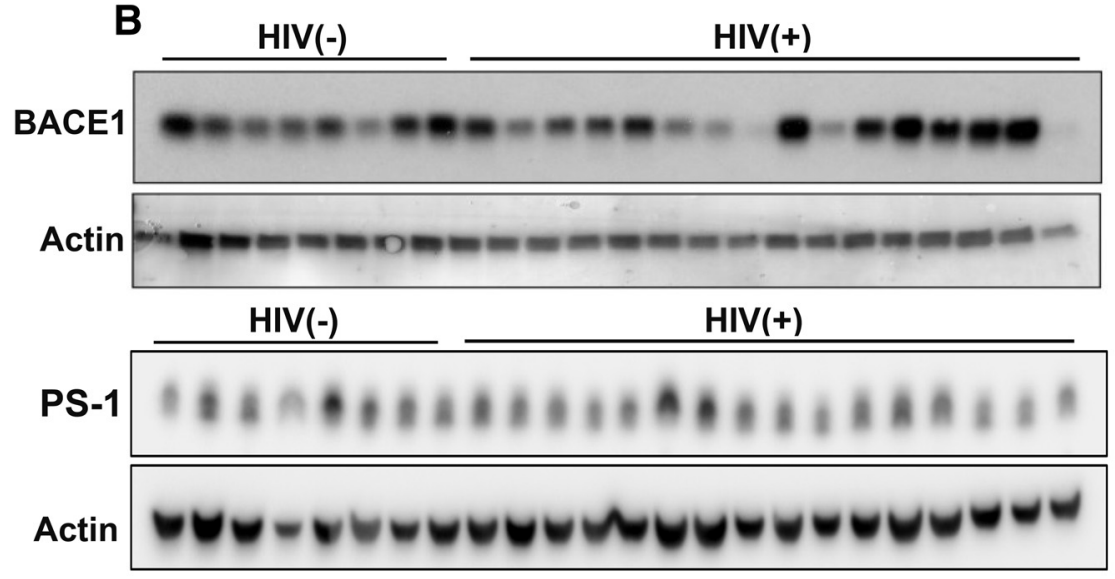

C

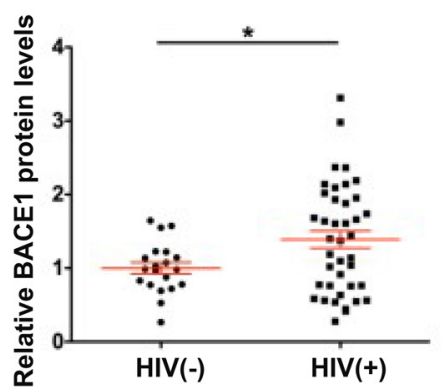

HIV(+)

HIV(+)

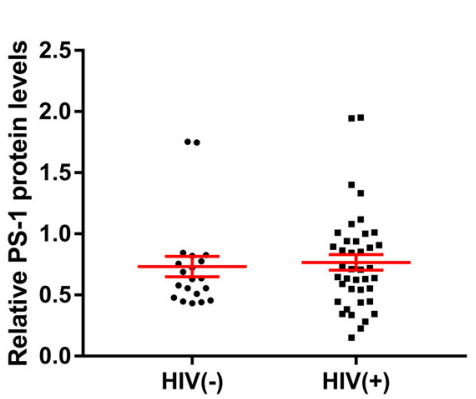

Figure 2. BACE1 but not PS1 protein is increased in frontal cortex of $\mathrm{HIV}^{+}$individuals. $A$, Lysates from the midfrontal cortex of HIV $^{-}$controls $(n=5)$ and HIV ${ }^{+}$cases $(n=13)$ were prepared for immunoblot and probed for BACE1. Representative blots are shown. FG, Fast Green loading control. $\boldsymbol{B}$, In an additional cohort, lysates from midfrontal cortex of HIV ${ }^{-}$controls $(n=20)$ and $\mathrm{HIV}^{+}$cases $(n=40)$ were prepared for immunoblot and probed for BACE1 and PS1, with actin as a loading control. Representative blots are shown. C, Results from the second cohort are quantified across all blots (ANOVA followed by Newman-Keuls, ${ }^{*} p<0.05$ ). Red lines indicate mean \pm SEM.

rcf for 10 min and undiluted supernatants were assayed with a rat $A \beta_{42^{-}}$ or $\mathrm{A} \beta_{40}$-specific sandwich ELISA (Wako Chemicals) according to the manufacturer's protocols. Luminescence was quantified using a 96-well plate reader measuring at $450 \mathrm{~nm}$. Raw concentrations (picomoles per liter) were normalized to MAP2 ${ }^{+}$cell counts for each treatment group.

Experimental design and statistical analysis. For all rat and mouse cell culture experiments, primary neuronal cultures prepared from one pregnant animal represented independent biological replicates, which were treated with vehicle or drug in the indicated combinations. An untreated condition (UT) was also included within each biological replicate and all results were normalized to this UT value. Paired $t$ tests (for two conditions) and repeated-measures ANOVA (for more than two conditions) were used to analyze these data to account for inherent correlations present within a single biological replicate. Except where otherwise indicated, data were analyzed using GraphPad Prism statistical software version 7.0 (RRID:SCR_002798) and are presented graphically as fold changes from UT \pm SEM, where the UT condition is represented by a dotted line. Because all UT values were set to 1 , they were not included within statistical analyses.

\section{Results}

\section{$\mathrm{A} \boldsymbol{\beta}$ oligomers are elevated in $\mathrm{HIV}^{+}$hippocampus}

Previous studies have shown accumulation of neurodegenerative proteins, such as APP and/or its cleavage products, in the brains of HANDs patients (Ortega and Ances, 2014). To investigate the mechanisms underlying age-related pathologies that are increasingly observed in HANDs, we first assessed levels of $A \beta$ oligomers ( $\mathrm{A} \beta$ oligo), the $\mathrm{A} \beta$ species suggested to be responsible for CNS neurotoxicity in $\mathrm{AD}$, in the hippocampus of $\mathrm{HIV}^{+}$patients and age-matched $\mathrm{HIV}^{-}$ controls in a cohort where eight of 10 $\mathrm{HIV}^{+}$patients had neurocognitive impairment (see Table 1 for a summary of cases). We used the Nab61 antibody that preferentially recognizes higher-order $\mathrm{A} \beta$ conformations including dimers and oligomers but excluding full-length APP and C-terminal fragments. We observed elevated levels of intraneuronal $\mathrm{A} \beta$ oligomers in $\mathrm{HIV}^{+}$patients (Fig. 1, Table 1). Importantly, we found no evidence of senile or diffuse $\mathrm{A} \beta$ plaque deposition in the hippocampus using the $\mathrm{A} \beta 42$-specific $\mathrm{BC} 05$ antibody (data not shown).

\section{BACE1 but not PS1 is increased in} frontal cortex of $\mathrm{HIV}^{+}$individuals Because oligomeric $\mathrm{A} \beta$ is derived from cleavage of APP by BACE1, we sought to determine whether BACE1 expression was altered in the same cohort of samples. Protein levels of BACE1 in whole-brain lysates from the midfrontal cortex of $\mathrm{HIV}^{-}$and $\mathrm{HIV}^{+}$individuals were assessed by immunoblotting. As shown in Figure $2 A$, BACE1 was elevated in $\mathrm{HIV}^{+}$ individuals compared with uninfected controls. We also replicated this result in the frontal cortex of a second independent cohort of $20 \mathrm{HIV}^{-}$and $40 \mathrm{HIV}^{+}$individuals, of whom 20 patients had HANDs (Table 2), confirming increased BACE1 in the frontal cortex of patients with HIV (Fig. $2 B, C$ ). In the second cohort, we assessed the levels of presenilin 1 (PS1), a $\gamma$-secretase core protein, which revealed that cortical PS1 levels were comparable between $\mathrm{HIV}^{-}$and $\mathrm{HIV}^{+}$ individuals (Fig. $2 B, C$ ).

\section{BACE1 is increased in primary neurons treated with supernatants from HIV/MDMs}

Based on our human data demonstrating a correlation between HIV seropositive status and elevated BACE1 levels, we used an in vitro model to investigate whether a causal relationship exists between HIV and BACE1. In this model, which has been described in detail previously (O'Donnell et al., 2006; Cross et al., 2011), macrophages derived from monocytes of healthy human donors are infected with HIV-1. Supernatants from infected macrophages (HIV/MDM) or uninfected macrophages (Mock) are then used to treat primary rat cortical neurons. As shown previously, HIV/MDM supernatant treatment caused loss of MAP2 ${ }^{+}$neurons after $24 \mathrm{~h}$ (Fig. 3A). To determine whether HIV/MDM supernatants induced BACE1 in neurons, we treated neuronal cultures with HIV/MDM supernatants for 16 or $24 \mathrm{~h}$. Cultures from each rat (independent biological replicates) were either untreated or treated with Mock or HIV/MDM supernatants generated from monocytes of the same human donor. By $16 \mathrm{~h}$, levels of 
Table 2. Summary of human cases used for immunoblotting in Figure $2, B$ and $C$

\begin{tabular}{|c|c|c|c|c|c|c|c|c|}
\hline $\begin{array}{l}\mathrm{HIV}^{-} \\
\text {subject ID }\end{array}$ & Age (y) & Sex & $\begin{array}{l}\text { PMI } \\
\text { (h) }\end{array}$ & $\begin{array}{l}\mathrm{HIV}^{+} \\
\text {subject ID }\end{array}$ & $\begin{array}{l}\text { Age } \\
\text { (y) }\end{array}$ & Sex & $\begin{array}{l}\text { PMI } \\
\text { (h) }\end{array}$ & $\begin{array}{l}\text { ART } \\
>12 \mathrm{mo}\end{array}$ \\
\hline Ctrl 1 & 40 & $M$ & 8.5 & HIV 1 & 35 & $M$ & 11.25 & - \\
\hline Ctrl 2 & 35 & $M$ & 8.5 & HIV 2 & 38 & $M$ & 3 & - \\
\hline Ctrl 3 & 46 & $M$ & 17.5 & HIV 3 & 52 & $M$ & 24 & - \\
\hline Ctrl 4 & 33 & $M$ & 15 & HIV 4 & 35 & $M$ & 7 & - \\
\hline Ctrl 5 & 47 & $\mathrm{~F}$ & 3.25 & HIV 5 & 45 & $M$ & N/A & - \\
\hline Ctrl 6 & 47 & $M$ & 9.5 & HIV 6 & 37 & $M$ & 5 & - \\
\hline Ctrl 7 & 48 & $M$ & 14 & HIV 7 & 32 & $M$ & 15.25 & - \\
\hline Ctrl 8 & 44 & $M$ & 9 & HIV 8 & 34 & $M$ & 6.25 & - \\
\hline Ctrl 9 & 41 & $M$ & 4 & HIV 9 & 43 & M & 2.75 & - \\
\hline Ctrl 10 & 43 & $M$ & 7 & HIV 10 & 42 & $M$ & 5.5 & - \\
\hline Ctrl 11 & 40 & $M$ & 15 & HIV 11 & 45 & $F$ & 2.5 & - \\
\hline Ctrl 12 & 33 & $F$ & 7.5 & HIV 12 & 43 & $\mathrm{~F}$ & 9.33 & - \\
\hline Ctrl 13 & 39 & $M$ & 7.75 & HIV 13 & 57 & $M$ & 14 & - \\
\hline Ctrl 14 & 35 & $F$ & 3.5 & HIV 14 & 43 & $M$ & 12 & - \\
\hline Ctrl 15 & 46 & $M$ & 16 & HIV 15 & 31 & $M$ & 8 & - \\
\hline Ctrl 16 & 45 & $M$ & 3.25 & HIV 16 & 46 & $M$ & 6 & - \\
\hline Ctrl 17 & 52 & $M$ & 4 & HIV 17 & 41 & $M$ & 20 & - \\
\hline Ctrl 18 & 50 & M & 5.75 & HIV 18 & 34 & $M$ & 19.25 & - \\
\hline Ctrl 19 & 47 & M & 21.5 & HIV 19 & 33 & $M$ & 3.75 & - \\
\hline \multirow[t]{21}{*}{ Ctrl 20} & 46 & $\mathrm{~F}$ & 19 & HIV 20 & 28 & M & 15.5 & - \\
\hline & & & & HIV 21 & 56 & $M$ & 12 & + \\
\hline & & & & HIV 22 & 42 & $M$ & 27.25 & + \\
\hline & & & & HIV 23 & 41 & $F$ & 6.5 & + \\
\hline & & & & HIV 24 & 39 & $M$ & 6 & + \\
\hline & & & & HIV 25 & 50 & $M$ & 12.5 & + \\
\hline & & & & HIV 26 & 46 & $F$ & 4.75 & + \\
\hline & & & & HIV 27 & 50 & $M$ & 13 & + \\
\hline & & & & HIV 28 & 34 & $F$ & 29 & + \\
\hline & & & & HIV 29 & 37 & $M$ & 12 & + \\
\hline & & & & HIV 30 & 55 & $F$ & 7 & + \\
\hline & & & & HIV 31 & 48 & $\mathrm{~F}$ & 7.5 & + \\
\hline & & & & HIV 32 & 49 & M & 6 & + \\
\hline & & & & HIV 33 & 50 & $M$ & 18 & + \\
\hline & & & & HIV 34 & 50 & M & 21 & + \\
\hline & & & & HIV 35 & 54 & $M$ & 12 & + \\
\hline & & & & HIV 36 & 36 & $M$ & $\mathrm{~N} / \mathrm{A}$ & + \\
\hline & & & & HIV 37 & 41 & $M$ & 13 & + \\
\hline & & & & HIV 38 & 48 & $M$ & 3 & + \\
\hline & & & & HIV 39 & 36 & $M$ & 2.5 & + \\
\hline & & & & HIV 40 & 44 & $M$ & 22 & + \\
\hline
\end{tabular}

N/A, Not available; PMI, postmortem interval.

BACE1 protein were increased in HIV/MDM-treated but not Mock-treated neurons (Fig. 3B,C). We then tested whether the effects on BACE1 were consistent across multiple supernatants from different donors. We collected supernatants generated from three individual healthy monocyte donors (independent biological replicates) and treated neurons from a single rat with Mock or HIV/MDM supernatants from each of the three donors for $16 \mathrm{~h}$. Levels of BACE1 protein were increased by treatment with all three supernatants tested (Fig. $3 D, E$ ).

\section{BACE1 increase by HIV/MDM supernatants is dependent on NMDAR signaling}

Increased glutamate and activation of NMDAR glutamate receptors are critical components of neurotoxicity in HANDs and AD (Kaul et al., 2001; Kocahan and Doğan 2017), as well as in our model (O'Donnell et al., 2006). Therefore, we investigated whether NMDARs are required for BACE1 induction. To test this, we pretreated primary rat neurons with either the NMDAR inhibitor MK801 or AP-5 or the glutamate receptor AMPAR inhibitor CNQX $1 \mathrm{~h}$ before 16 or $24 \mathrm{~h}$ of treatment with HIV/MDM or Mock supernatants. As observed previously, neurotoxicity of
HIV/MDM supernatant treatment was blocked by pretreatment with MK801 or AP-5, whereas CNQX had no effect after $24 \mathrm{~h}$ (Fig. 4A). Correspondingly, induction of BACE1 by HIV/MDM supernatant treatment was blocked by pretreatment with MK801 or AP-5 but not CNQX after 16 h (Fig. $4 B$ ). These results are quantified in Figure 4, $C$ and $D$. Having demonstrated the necessity for NMDAR signaling in BACE1 upregulation, we next investigated whether NMDAR activation was sufficient for upregulation of BACE1. Indeed, we observed a significant, dose-dependent increase in BACE1 protein levels in rat primary neurons after $16 \mathrm{~h}$ of treatment with NMDA alone (Fig. 4E,F).

\section{NMDAR activation shifts APP processing toward the amyloidogenic pathway}

In neurons, full-length APP can be cleaved by either ADAM10 or BACE1 and, in either case, is subsequently cleaved by PS1. Cleavage by ADAM10/PS1 generates the nonamyloidogenic fragment P3, whereas BACE1/PS1 cleavage generates $\mathrm{A} \beta$ monomers that can oligomerize to form disease-associated peptides, fibrils, and plaques. Because we found that NMDAR signaling was both necessary and sufficient for BACE1 induction and neurotoxicity induced by HIV/MDM supernatants, in the next series of experiments, we treated primary rat neurons directly with NMDA for 10 min or $2,8,16,24$, or $48 \mathrm{~h}$ to assess changes in APP processing and secretase expression. Because NMDA is a synthetic compound, we also treated neurons with the endogenous NMDA ligand glutamate to ensure physiological relevance of our results. Treatment with either NMDA or glutamate for $16 \mathrm{~h}$ increased both BACE1 and PS1 protein levels and dramatically decreased ADAM10 protein levels (Fig. 5A-D). Corresponding neuronal cultures were fixed for $10 \mathrm{~min}$ or $2,8,16,24$, or $48 \mathrm{~h}$ after NMDA treatment. Consistent with changes in protein expression playing a role in NMDA-induced neurotoxicity, significant loss of MAP2 ${ }^{+}$cells did not occur until $24 \mathrm{~h}$ after treatment with NMDA (Fig. 5E). Next, we investigated whether changes in secretase expression patterns were accompanied by changes in the production of BACE1 cleavage product $\mathrm{A} \beta_{42}$. To test this, we collected supernatants from primary rat neurons treated with NMDA for 16 or $24 \mathrm{~h}$ and measured the concentration of secreted monomers of $\mathrm{A} \beta_{42}$ with a high-sensitivity ELISA. After $24 \mathrm{~h}, \mathrm{~A} \beta_{42}$ concentration normalized to $\mathrm{MAP}^{+}{ }^{+}$cells was increased in NMDA-treated neuron supernatants (Fig. $5 F$ ).

\section{Neurotoxicity induced by either NMDA or HIV/MDM supernatants is partially dependent on BACE1 and PS1 activity}

Because NMDA treatment caused both BACE1 increases and neurotoxicity, we investigated whether BACE1 activity plays a role in the mechanism of neuronal death induced by NMDA. Rat primary neurons were pretreated with a pharmacological BACE1 inhibitor (BSI) for $1 \mathrm{~h}$ before $24 \mathrm{~h}$ treatment with NMDA and BSI pretreatment significantly decreased NMDA-induced neurotoxicity (Fig. 6A,B). To further evaluate the role of the amyloidogenic pathway in neurotoxicity, we performed a separate set of experiments in which primary rat neurons were pretreated with the $\gamma$-secretase inhibitor MRK $1 \mathrm{~h}$ before NMDA treatment. Similarly to BACE1 inhibition, $\gamma$-secretase attenuated NMDAinduced neurotoxicity (Fig. 6C,D). Finally, to confirm the role of BACE1 in neurotoxicity of our in vitro HIV model, we also pretreated rat primary neurons with BSI for $1 \mathrm{~h}$ before $24 \mathrm{~h}$ treatment with HIV/MDM or Mock supernatants. Again, neurotoxicity was attenuated by BSI pretreatment (Fig. 6E,F). 


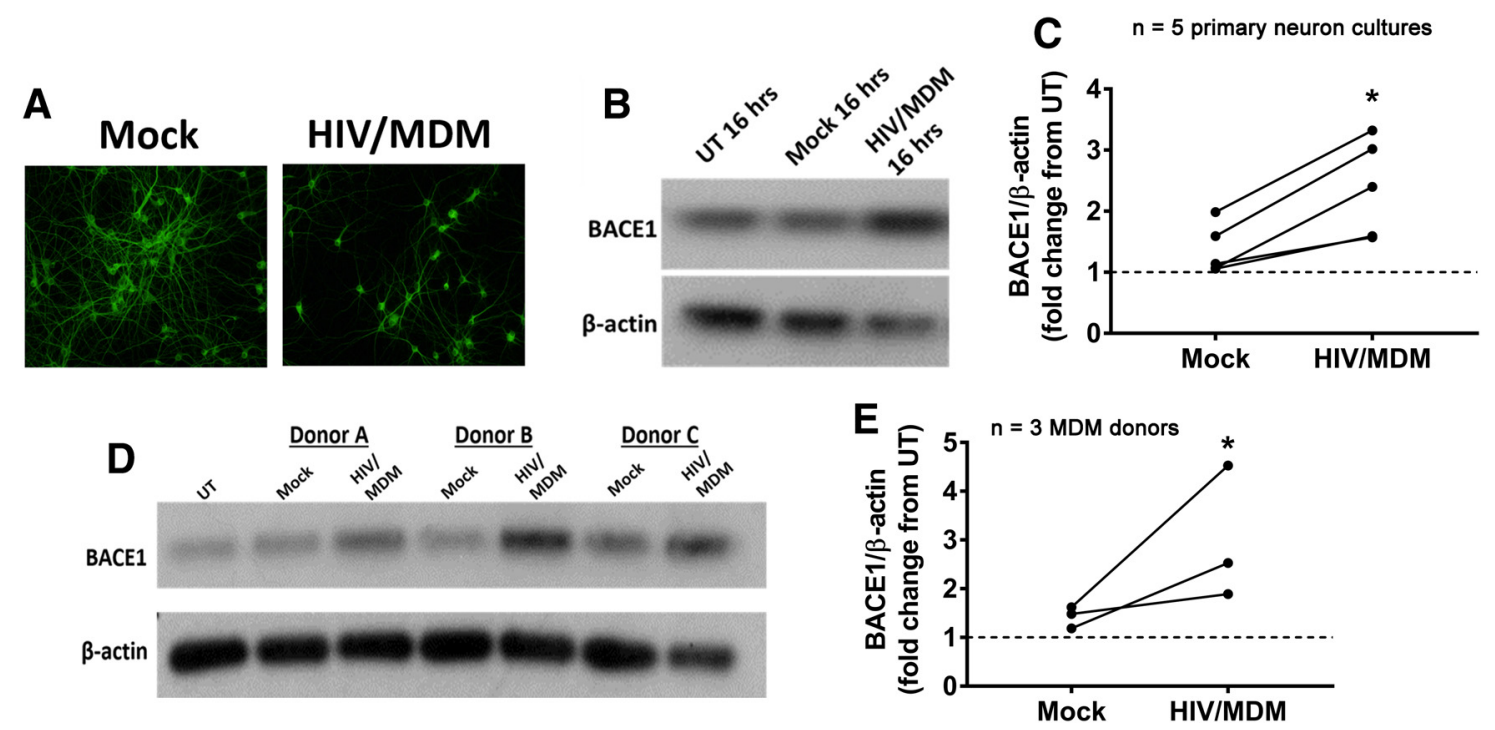

Figure 3. BACE1 is increased in primary neurons after treatment with HIV/MDMs. A, Each biological replicate of primary rat neurons was treated with Mock or HIV/MDM supernatants at a dilution causing 50\% MAP2 loss after 24h. Representative images of MAP2 (green) are shown. $\boldsymbol{B}$, Whole-cell lysates were collected after $16 \mathrm{~h}$ treatment with Mock or HIV/MDM supernatants generated from the monocytes of a single human donor and lysates were probed for BACE1. Representative blots are shown. $C$, Within each rat (biological replicate), BACE1/ $\beta$-actin for both Mock and HIV/MDM treatment conditions were compared with UT and fold changes from UT were averaged across all biological replicates. To account for inherent correlations within neuronal cultures generated from the same rat, data were analyzed by paired (dependent samples) $t$ test comparing the Mock and HIV/MDM treatment conditions. Densitometric analysis of Western blots revealed a significant increase in BACE1/ $\beta$-actin after $16 \mathrm{~h} \mathrm{HIV/MDM} \mathrm{treatment} \mathrm{(paired} \mathrm{ttest,} n=5,{ }^{*} p<0.05$ ). Dotted lines represent UT cultures. D, HIV/MDM supernatants were generated from three separate healthy monocyte donors and used to treat primary neurons generated from a single rat for $16 \mathrm{~h}$. The resulting blot is shown. $E$, Within each individual monocyte donor, BACE1/ $\beta$-actin for both Mock and HIV/MDM treatment conditions were compared with UT and fold changes from UT were averaged across all monocyte donors. Here, each donor was an independent biological replicate and data were analyzed by paired (dependent samples) $t$ test to account for inherent correlations between Mock and HIV/MDM supernatants generated from a single human donor. Increases in BACE 1 by $16 \mathrm{~h}$ HIV/MDM treatment were consistent across HIV/MDM and Mock supernatants generated from multiple monocyte donors (paired $t$ test, $n=3,{ }^{*} p<0.05$ ). Dotted lines represent UT cultures.

\section{BACE1-mediated NMDA-induced neurotoxicity is dependent on the expression of APP}

BACE1 cleaves several protein targets in addition to APP, including sodium and potassium channels, cell adhesion-related proteins, and others (Kim et al., 2007; Munro et al., 2016). Therefore, we investigated whether the critical function of BACE1 responsible for its role in NMDA-induced neurotoxicity was dependent on the presence of APP. To test this, neuroglia were isolated from either WT or APP ${ }^{-1-}$ mouse cortex at embryonic day 1618. Neuroglial cultures isolated from $\mathrm{APP}^{-/-}$mice were viable and had undetectable levels of APP (Fig. 7A). Consistent with our observations in rat neuronal cultures, NMDA induced BACE1 expression in both WT and $\mathrm{APP}^{-1-}$ mouse neuroglia, indicating that cells were responsive to NMDA at the level of changes in BACE1 expression (Fig. 7B). At the level of neurotoxicity, however, $\mathrm{APP}^{-1-}$ cultures showed a striking resistance to NMDAinduced insult compared with WT cultures, with both higher NMDA concentrations and longer treatments needed to cause the same degree of MAP2 loss (Fig. 7C,D). Specifically, whereas $5 \mu \mathrm{M}$ NMDA led to $\sim 50 \% \mathrm{MAP}^{+}{ }^{+}$cell loss after 24 h of treatment in WT cultures, $10 \mu \mathrm{M}$ NMDA was required to induce the same level of toxicity in $\mathrm{APP}^{-1-}$ cells and $5 \mu \mathrm{M}$ NMDA treatment had no effect (Fig. 7E). To determine whether APP was specifically required for the role of BACE1 in NMDA-induced toxicity, we then investigated whether the remaining portion of NMDAinduced neurotoxicity in $\mathrm{APP}^{-1-}$ cells was BACE1 dependent. To test this, we first confirmed BACE1 dependence of NMDAinduced neurotoxicity in WT mouse cultures by pretreating cells with BSI for $1 \mathrm{~h}$ before $24 \mathrm{~h}$ treatment with $5 \mu \mathrm{M}$ NMDA. Similar to our observations in primary rat neurons, BACE1 inhibition significantly decreased neurotoxicity (Fig. $7 F, H)$. We then repeated this experiment in $\mathrm{APP}^{-1-}$ cells, with the exception that $10 \mu \mathrm{M}$ NMDA was used to induce a similar level of toxicity $(\sim 50 \%$
$\mathrm{MAP}^{+}{ }^{+}$cell loss) as $5 \mu \mathrm{M}$ NMDA treatment in the WT (Fig. 7E). In $\mathrm{APP}^{-1-}$ cells, BACE1 inhibition had no effect on NMDA-induced neurotoxicity after $24 \mathrm{~h}$ (Fig. 7G,I).

\section{Discussion}

In the present study, we show that both BACE1 and $\mathrm{A} \beta$ oligomers are increased in the hippocampus and frontal cortex of ARTtreated $\mathrm{HIV}^{+}$patients and demonstrate a mechanistic role for both BACE1 and APP in HIV-associated in vitro neurotoxicity. Moreover, by clearly showing a necessity and sufficiency of NMDAR activation in engaging this mechanism, we implicate a role for BACE1 in classic excitotoxicity pathways relevant not only to HANDs, but also to neurodegenerative diseases more broadly (Lipton and Rosenberg, 1994; Carvajal et al., 2016; Kocahan and Doğan 2017).

These data add to a growing body of evidence that there are overlapping neuropathological mechanisms in AD and HANDs. $\mathrm{A} \beta$ oligomers are thought to be the toxic species promoting neuropathogenesis in AD (Kayed and Lasagna-Reeves, 2013) and our data indicate that they may play a similar role in HANDs. BACE1 is increased in postmortem brains of $\mathrm{AD}$ patients (Yang et al., 2003; Johnston et al., 2005) and, in animal models of AD, BACE1 inhibitors reverse neuronal loss and cognitive deficits (Ohno et al., 2004; Singer et al., 2005; Chang et al., 2011). To our knowledge, our study provides the first evidence that BACE1 is similarly altered in $\mathrm{HIV}^{+}$patient brains and that exposure to cultured media from HIV-infected MDMs can increase BACE1 levels in neurons.

First, we demonstrated differences in BACE1 levels in two separate cohorts of $\mathrm{HIV}^{+}$patients that provided tissue from two different brain regions, hippocampus and dorsolateral prefrontal cortex, each of which is damaged during the course of HIV infection. Although these cohorts were not demographically matched, 
due to availability of tissue, the data derived from each supports the conclusion that BACE1 expression is increased in $\mathrm{HIV}$-affected brain regions. In addition, the difference in the cognitive impairment status between the two cohorts is another important caveat. Samples in the first cohort were collected earlier in the HIV pandemic, during which first-generation diagnostic neurocognitive criteria were applied. In this cohort, eight of $10 \mathrm{HIV}^{+}$ patients $(80 \%)$ were diagnosed with symptomatic HANDs, termed at the time as minor cognitive motor disorder and HIV-associated dementia (HAD), with five of the patients diagnosed with HAD, and were compared with $\mathrm{HIV}^{-}$patients. In our second cohort, 20 of $40 \mathrm{HIV}^{+} \mathrm{pa}-$ tients were diagnosed with HANDs (50\%), of whom only seven had HAD. A final caveat is that each cohort contributed different brain regions for examination, hippocampus versus frontal cortex. Therefore, the variability observed between the cohorts reflects the range in clinical presentation and difference in brain regions. Despite these caveats, our studies suggest that increased BACE1 levels associated with HIV infection affect distinct, pathologically relevant brain regions.

We and others have also shown that BACE1 is increased by antiretroviral drugs of at least two classes (Brown et al., 2014; Gannon et al., 2017), implying that ARTtreated $\mathrm{HIV}^{+}$patients may have additive increases in BACE1 due to influence of both the viral infection and the therapeutic intervention. In addition, we provided evidence here for a mechanistic role of BACE1 in HIV-associated neurotoxicity in vitro. Future studies should thus investigate whether BACE1 inhibitors reverse neuronal damage and cognitive deficits in rodent and nonhuman primate models of HANDs.

Interestingly, we found that the HIVassociated increase in BACE1 was mirrored by an increase in the APP $\gamma$-secretase PS1 (Selkoe and Wolfe, 2000) and a corresponding decrease in the APP $\alpha$-secretase ADAM10 (Lammich et al., 1999). Increased PS1 after NMDAR activation has been observed previously (Mitsuda et al., 2001) and our ADAM10 observations are consistent with a previous study linking NMDARs with increased soluble APP alpha $(\operatorname{sAPP} \alpha)$ concentration in neurons and conditioned media (Lesné et al., 2005). To our knowledge, however, these results represent the first evidence of a direct influence of NMDAR activation on ADAM10 protein expression. Our observation highlights another potential similarity with neuropathogenesis in $\mathrm{AD}$, given that ADAM10 is decreased in both postmortem brain and CSF of AD patients (Colciaghi et al., 2002; Bernstein et al., 2003; Olsson et al., 2003; Fellgiebel et al., 2009). Changes in ADAM10 are likely to play an

FG

C
A UT
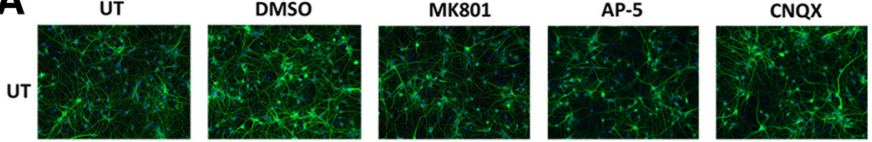

Mock $2,+1$,
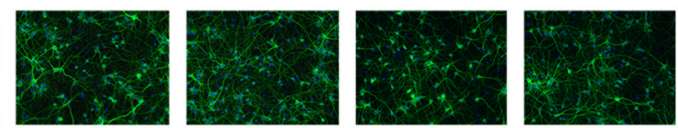

HIV/MDM
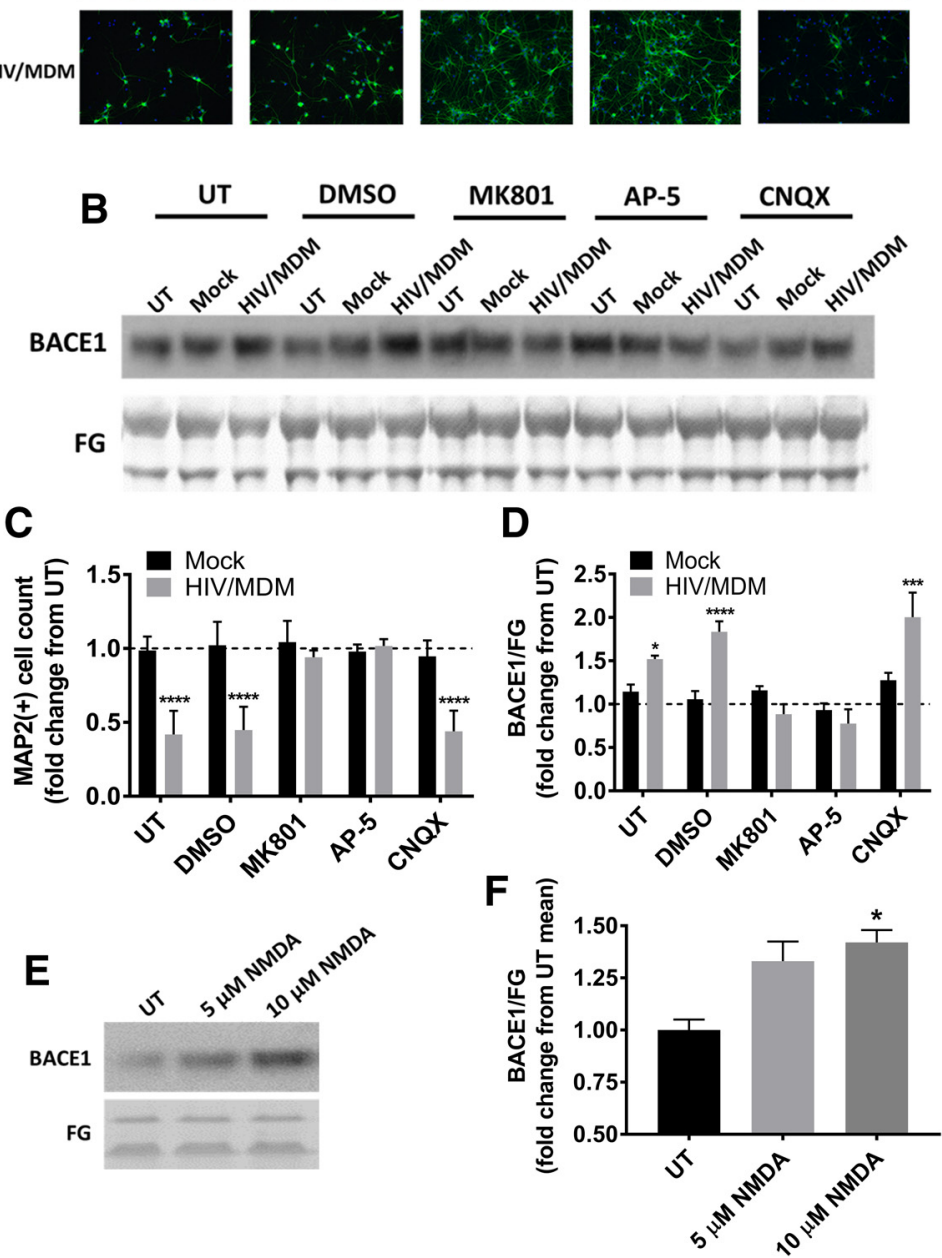

Figure 4. NMDAR signaling is necessary and sufficient for BACE1 upregulation by HIV/MDM supernatants. $A$, Primary rat neurons were pretreated for $1 \mathrm{~h}$ with $10 \mu \mathrm{M}$ NMDAR antogonist MK801, $100 \mu \mathrm{M}$ NMDAR antagonist AP-5, or $30 \mu \mathrm{M}$ AMPAR antagonist CNQX before $24 \mathrm{~h}$ treatment with Mock or HIV/MDM supernatants. Representative images are double labeled for MAP2 (green) and nuclei (blue). $\boldsymbol{B}$, Identical pretreatments were performed for a separate of cultures harvested after $16 \mathrm{~h}$ treatment with Mock or HIV/MDM supernatants. Representative blots are shown. C, Number of MAP2 ${ }^{+}$cells was quantified across $24 \mathrm{~h}$ treatment groups (repeated-measures two-way ANOVA followed by Dunnett's test, $\left.n=3,{ }^{* * * *} p<0.0001\right)$. D, Densitometric analysis of BACE1/FG was used to quantify levels of BACE1 protein across $16 \mathrm{~h}$ treatment groups (repeated-measures two-way ANOVA followed by Dunnett's test, $n=3,{ }^{*} p<0.05,{ }^{* * *} p<0.001,{ }^{* * * *} p<0.0001$ ). $\boldsymbol{E}$, Cultures were treated with 5, 10, or $20 \mu \mathrm{m}$ NMDA for $16 \mathrm{~h}$ and assessed for BACE1 protein levels. Representative blots are shown. $F$, Densitometric analysis of BACE1/FG was used to quantify levels of BACE1 protein (repeated-measures one-way ANOVA followed by Dunnett's test, $n=4-5,{ }^{*} p<0.05$ ). Dotted lines represent UT cultures. FG, Fast Green loading control.

important role in disease given that ADAM10 cleavage product sAPP $\alpha$ affords neuroprotection in a variety of contexts (Habib et al., 2017) and, moreover, a decrease in ADAM10 likely exacerbates the shift toward amyloidogenic APP cleavage due to increased BACE1 and PS1. Consistent with a role for the amyloidogenic pathway in promoting neurotoxicity, we observed that PS1 inhibition nd BACE1 inhibition was effective to attenuate NMDAinduced neurotoxicity in vitro. Because we observed increased BACE1 but not PS1 in vivo, our data together suggest that increases in BACE1 may primarily drive neurotoxicity, but that this 


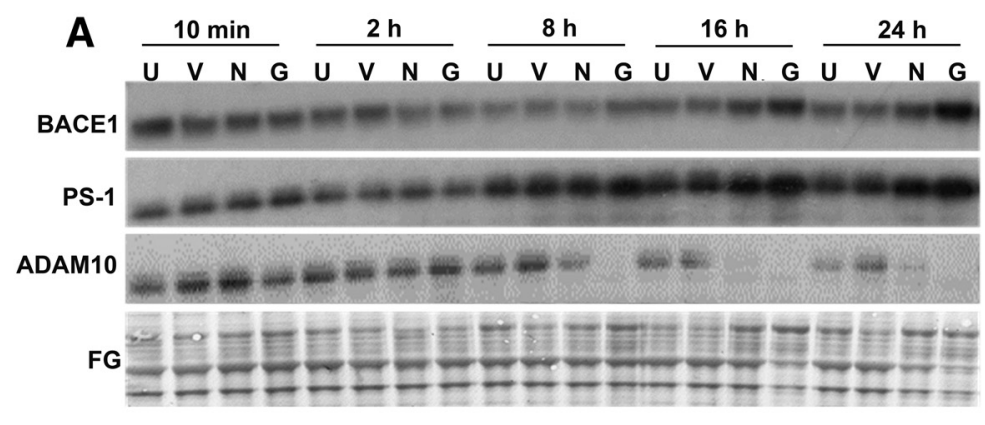

B

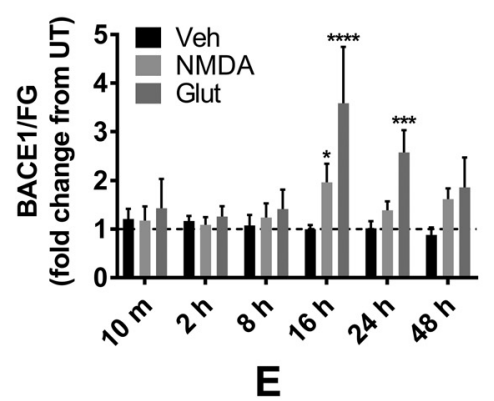

E
C

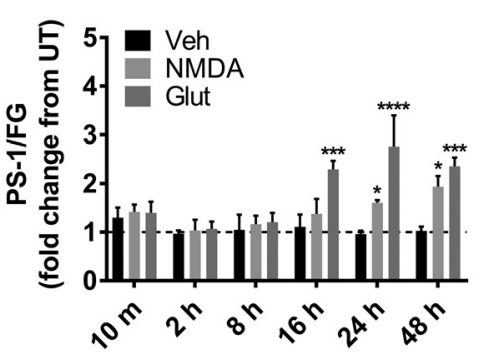

D

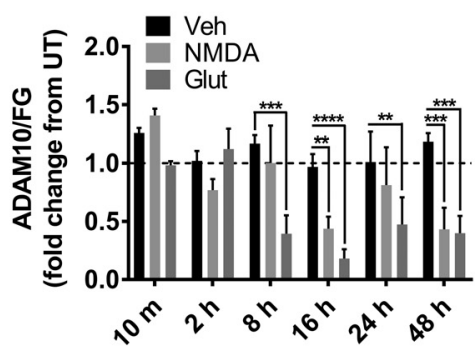

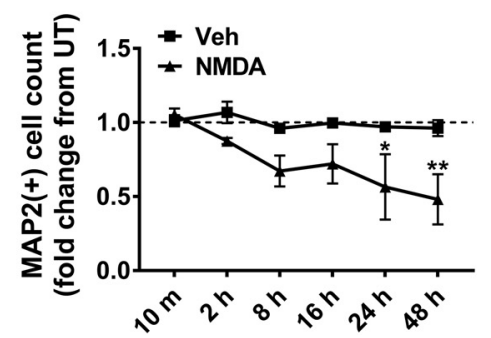

$\mathbf{F}$

Figure 5. NMDAR signaling shifts APP cleavage toward the amyloidogenic pathway. A, Primary rat neurons were treated with $10 \mu \mathrm{m} \mathrm{NMDA} \mathrm{or} 10 \mu \mathrm{m}$ glutamate for 10 min or $2,8,16,24$, or $48 \mathrm{~h}$. Whole-cell lysates were collected and assessed for BACE1, PS1, and ADAM10 expression; representative blots are shown. $\boldsymbol{B}-\boldsymbol{D}$, Densitometric analysis of each secretase compared with FG was used to quantify protein levels across time points (repeated-measures two-way ANOVA followed by Dunnett's test, $n=3-4,{ }^{*} p<0.05,{ }^{* *} p<0.01$, ${ }^{* * *} p<0.001$, ${ }^{* * * *} p<0.0001$ ). FG, Fast Green loading control. $E$, Number of $\mathrm{MAP2}^{+}$cells was quantified after $10 \mu \mathrm{M}$ NMDA treatment (repeated-measures two-way ANOVA followed by Sidak's test, $n=4,{ }^{*} p<0.05,{ }^{* *} p<0.01$ ). $F$, Conditioned media from primary rat neurons were collected after $24 \mathrm{~h}$ treatment with $10 \mu \mathrm{M}$ NMDA and sample concentrations of A $\beta 42$ were measured using a sandwich ELISA. Concentrations were normalized to the number of $\mathrm{MAP}^{+}{ }^{+}$cells in identically treated cultures within each biological replicate (paired $t$ test, $n=3,{ }^{*} p<0.05$ ). Dotted lines represent UT cultures.

neurotoxicity is also partially dependent on downstream cleavage by PS1 to eventually form A $\beta$.

Although BACE1 is well known for its role in APP cleavage, it has other cleavage targets, including proteins involved in development, synaptic function, and cell-cell adhesion (Munro et al., 2016). Therefore, it is critical that, in our study, we determined that the mechanistic role of BACE1 in NMDA-induced neurotoxicity was dependent on the presence of APP, indicating that APP cleavage was indeed the relevant BACE1 function responsible for toxicity in our model. Consistent with this, genetic loss of APP alone also conferred resistance of neurons to NMDA-induced toxicity. Within the context of abnormal APP processing observed in brains of HIV patients here and in other studies (Green et al., 2005; Ortega and Ances, 2014), these results indicate a potential pathogenic role for altered APP processing in HANDs independent of plaque formation.

In apparent contradiction, however, previous studies have demonstrated both decreased cell viability and increased sensitivity to excitotoxic insult in cultured neurons lacking APP (Perez et al., 1997; Han et al., 2005). Others have reported no differences in susceptibility (Harper et al., 1998; White et al., 1998) and another study found similar results to ours, albeit with copper-induced neu- rotoxicity rather than direct excitotoxic insult (White et al., 1999). In addition, Verges et al. (2011) reported increased levels of PS1 in PS1/APP transgenic mouse brain after treatment with an NMDAR antagonist. These discrepancies may be due to critical differences in the downstream effects of NMDAR activation depending on the dose and time course in question. Indeed, NMDA exerts opposing effects on extracellular $\mathrm{A} \beta$ accumulation in vivo depending on the dose, with lower doses increasing amyloidogenic APP processing and higher doses causing a decrease (Verges et al., 2011). Although Han et al. (2005) used a $300 \mu \mathrm{M}$ dose of NMDA for $15 \mathrm{~min}$, we used doses within the 5-20 $\mu \mathrm{M}$ range for longer exposures, attempting to mimic a more chronic disease process. Depending on the precise neuronal microenvironment and pathological stage, both mechanisms are likely to play a role given that the acute protective effects of sAPP $\alpha$ must compete against the more chronic detrimental effects of the amyloidogenic pathway (Hefter and Draguhn, 2017).

Also consistent with our observation that loss of APP confers resistance to NMDA-induced neurotoxicity, one series of studies has demonstrated a role for APP in trafficking NMDARs to the cell surface and increasing postsynaptic excitatory currents (Cousins et al., 2009; Hoe et al., 2009; Innocent et al., 2012; Cousins et al., 
A
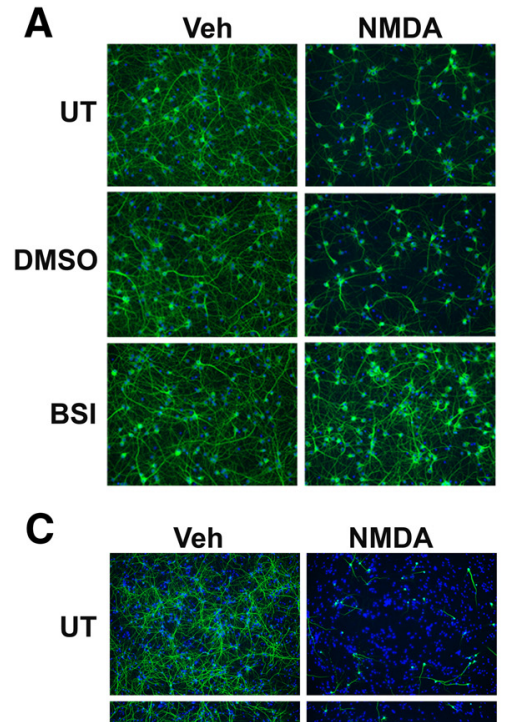

NMDA
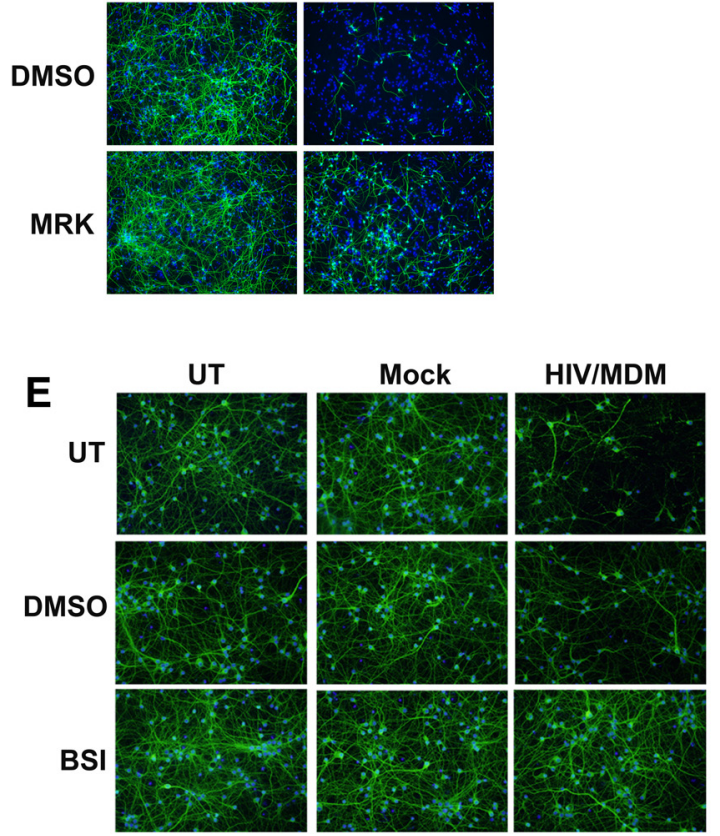

B
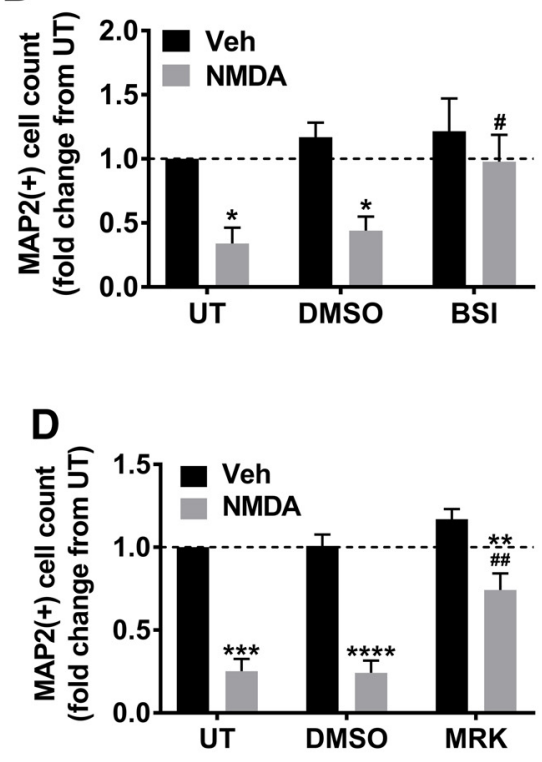

$\mathbf{F}$

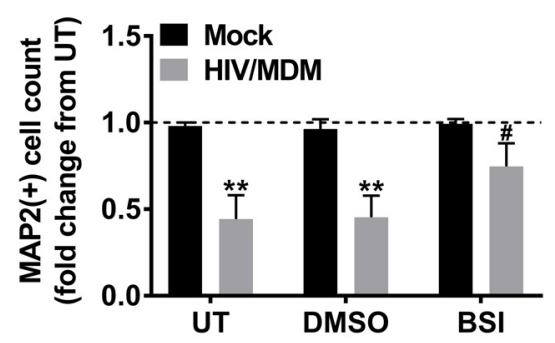

Figure 6. Neurotoxicity induced by either NMDA or HIV/MDM supernatants is dependent on BACE1 activity. A, Primary rat neurons were pretreated with DMSO vehicle or $100 \mathrm{~nm}$ BSI II for $1 \mathrm{~h}$ before $24 \mathrm{~h}$ treatment with $10 \mu \mathrm{m}$ NMDA. Representative images are double labeled for MAP2 (green) and nuclei (blue). $\boldsymbol{B}$, Number of MAP2 ${ }^{+}$cells was quantified across treatment groups (repeatedmeasures two-way ANOVA followed by Tukey's test, $n=4,{ }^{*} p<0.05$ vs treatment vehicle, $\# p<0.05$ vs pretreatment vehicle). C, Primary rat neurons were pretreated with DMSO vehicle or 0.5 $\mu \mathrm{M}$ MRK for $1 \mathrm{~h}$ before $24 \mathrm{~h}$ treatment with $10 \mu \mathrm{m}$ NMDA. Representative images are double labeled for MAP2 (green) and nuclei (blue). D, Number of MAP2 ${ }^{+}$cells was quantified across treatment groups (repeated-measures two-way ANOVA followed by Tukey's test, $n=5,{ }^{* *} p<0.05,{ }^{* * *} p<0.01,{ }^{* * * *} p<0.001$ vs treatment vehicle; \#\#p $<0.01$ vs pretreatment vehicle). E, Primary rat neurons were pretreated with DMSO vehicle or $5 \mu \mathrm{M}$ BSI IV for $1 \mathrm{~h}$ before $24 \mathrm{~h}$ of treatment with Mock or HIV/MDM supernatants. Representative images are double labeled for MAP2 (green) and nuclei (blue). $\boldsymbol{F}$, Number of MAP2 ${ }^{+}$cells was quantified across treatment groups (repeated-measures two-way ANOVA followed by Tukey's test, $n=4,{ }^{* *} p<0.01$ vs Mock, \#p $<0.05$ vs pretreatment vehicle). Dotted lines represent UT cultures.

2015). This may be a contributing factor to our results as well, particularly given that NR2B subunit localization is selectively affected by APP (Hoe et al., 2009) and in large part NR2B subunits mediate the neurotoxicity in our in vitro HIV model (O'Donnell et al., 2006). Important to note, however, is that although loss of APP shifted the toxicity dose curve of NMDA, the effect of NMDA on BACE1 expression was not changed. This indicates that toxicity resistance was not entirely due to changes in surface expression and may instead have resulted from decreased BACE1-dependent toxic mechanisms.

Classical pathways of excitotoxic injury are well characterized, but there are several ways that a role for BACE1 may fit within these pathways or within a parallel apoptotic or necrotic mecha- nism. For instance, Lesné et al. (2005) found that changes in APP cleavage product concentrations induced by NMDA were prevented by either a calcium chelator or inhibition of calmodulin/ calmodulin kinase. Given our observation of increased BACE1 expression after NMDA treatment, one possibility is that BACE1 levels are directly affected by either calcium or calcium-dependent enzymes. BACE1 is also increased in vitro by calpain (Dong et al., 2006; Liang et al., 2010), another critical factor in excitotoxic injury. Possible parallel mechanisms of BACE1-mediated toxicity due to NMDAR activation include oxidative stress-dependent pathways (Tong et al., 2005) and the unfolded protein response (O'Connor et al., 2008), which mediates BACE1 upregulation in response to HIV protease inhibitors (Gannon et al., 2017). Because 
A

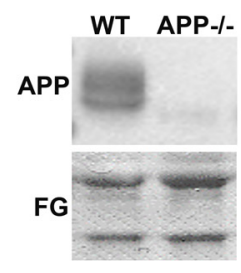

B

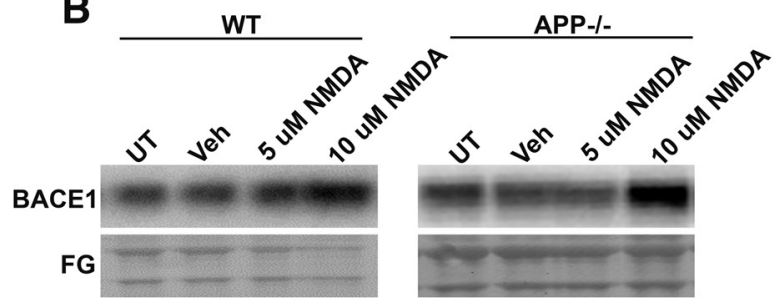

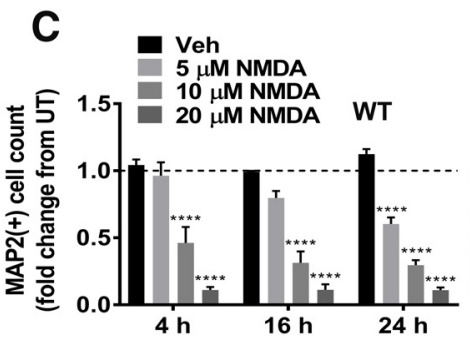

$\mathbf{F}$

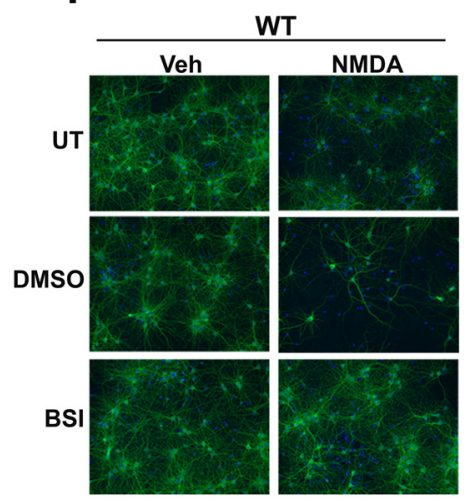

D

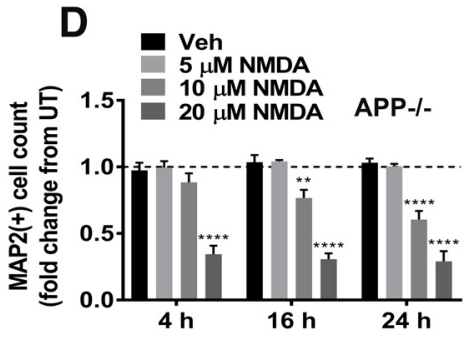

E

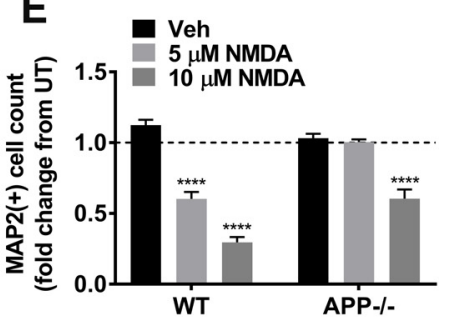

H
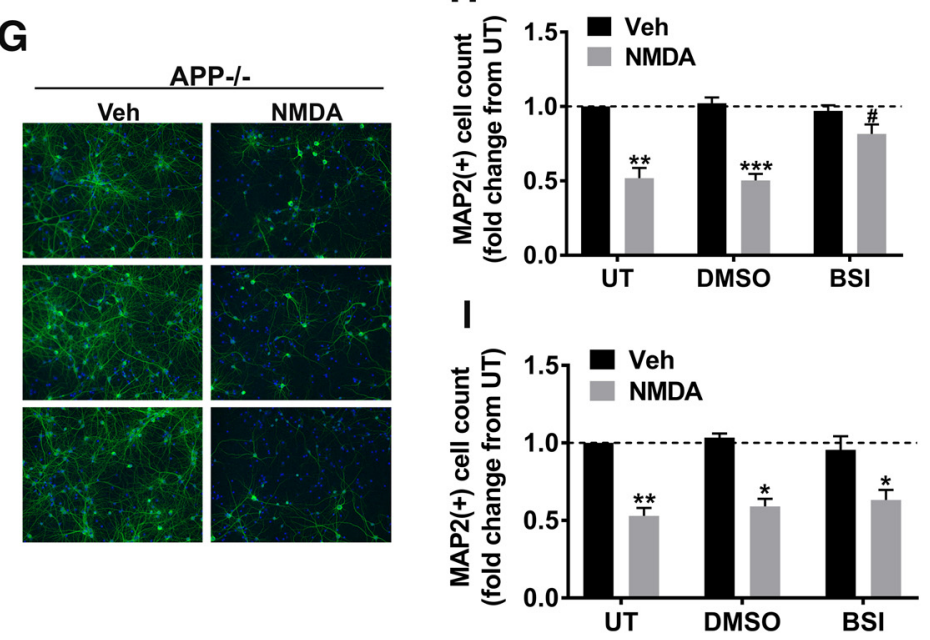

Figure 7. APP is required for BACE1-dependent NMDA-induced neurotoxicity. A, Primary neuroglia were isolated from WT or APP ${ }^{-1-}$ mice and assessed for levels of APP by Western blot. Representative blots are shown. B, WT or APP ${ }^{-1-}$ neuroglial cultures were treated with 5 or $10 \mu \mathrm{m} \mathrm{NMDA} \mathrm{for} 16 \mathrm{~h}$ and whole-cell lysates were collected and assessed for BACE1. Representative blots are shown. FG, Fast Green loading control. C, D, WT (C) and APP ${ }^{-1-}(\boldsymbol{D})$ cultures were treated with 5, 10, or $20 \mu \mathrm{m} \mathrm{NMDA} \mathrm{for} \mathrm{4,} \mathrm{16,} \mathrm{or} 24 \mathrm{~h}$. Number of MAP2 ${ }^{+}$cells was quantified across treatment groups (two-way ANOVA followed by Dunnett's test, $n=3-5,{ }^{* *} p<0.01,{ }^{* * * *} p<0.0001$ vs vehicle control). $E$, Data from $($ and $D 5$ and $10 \mu \mathrm{m} 24 \mathrm{~h}$ NMDA treatment groups only were replotted to show direct comparison between WT and APP ${ }^{-1-}$ responses (two-way ANOVA follows by Dunnett's test, $n=3-5,{ }^{* * * *} p<0.0001$ vs vehicle control). $\boldsymbol{F}, \boldsymbol{G}, \mathrm{WT}(\boldsymbol{F})$ and APP ${ }^{-1-}(\boldsymbol{G})$ cultures were pretreated with DMSO vehicle or BSI for $1 \mathrm{~h}$ before $24 \mathrm{~h}$ treatment with $5 \mu \mathrm{M}$ (WT) or $10 \mu \mathrm{m}$ (APP ${ }^{-1-}$ ) NMDA. Representative images are double labeled for MAP2 (green) and nuclei (blue). $\boldsymbol{H}, \mathbf{I}$, Number of MAP2 ${ }^{+}$cells was quantified across treatment groups (repeated-measures two-way ANOVA followed by Dunnett's test, $n=3-4,{ }^{*} p<0.05,{ }^{* *} p<0.01$, ${ }^{* * *} p<0.001$ ). Dotted lines represent UT cultures. \# indicates $p<0.05$ compared with DMSO pretreatment.

several mechanisms can potentially increase BACE1 activity and/or upregulate its expression, the particular pathway engaged likely depends on multiple factors and the possibilities are not mutually exclusive.

Aside from identifying a specific role for BACE1, our study adds to a body of literature implicating critical roles for glutamate and NMDA signaling in HIV neuropathogenesis. Indeed, NMDARs are downregulated in brains of HIV encephalitis patients (Masliah et al., 2004) and HIV dementia patients have increased CSF glutamate levels that are correlated with the degree of neurocognitive impairment (Ferrarese et al., 1997, 2001). In the recently developed EcoHIV mouse model, HIV-stimulated release of cytokines from microglia impaired astrocytic reuptake of glutamate, increasing glutamate in the extracellular space and causing NMDAdependent excitotoxicity (Moidunny et al., 2016). In addition, viral proteins gp120 and tat can also activate NMDARs directly (Fontana et al., 1997; Shin et al., 2012; Zhou et al., 2017) and increase neuronal glutamate release (Gupta et al., 2010) and NMDA antagonists are neuroprotective in gp120 and tat rodent models of HIV (Mucke et al., 1995; Anderson et al., 2004). Indeed, a set of elegant experiments by Lipton et al. in 1991 indicated that both glutamate and gp120 act synergistically to induce calcium currents and subsequent toxicity. This indicates that both increased glutamate and free viral particles may act in parallel to disrupt NMDA signaling in HIV-infected individuals.

In summary, we have provided further evidence for the involvement of BACE1 and altered APP cleavage in HANDs, with a potential role for $A \beta$ oligomers in particular. Few studies in the era of combined ART have provided clear neuropathological differences between virally suppressed $\mathrm{HIV}^{+}$individuals and $\mathrm{HIV}^{-}$ controls (Gelman, 2015), further highlighting the significance of this work and the potential importance of BACE1 as a biomarker or therapeutic target. Moreover, by identifying both NMDAR signaling and altered APP processing as critical factors mediating 
the role of BACE1 in HIV-associated neurotoxicity, we provide support for the potential efficacy of several avenues for therapeutic intervention in HANDs in addition to direct pharmacological targeting of BACE1.

\section{References}

Achim CL, Adame A, Dumaop W, Everall IP, Masliah E; Neurobehavioral Research Center (2009) Increased accumulation of intraneuronal amyloid beta in HIV-infected patients. J Neuroimmune Pharmacol 4:190199. CrossRef Medline

Akay C, Lindl KA, Wang Y, White MG, Isaacman-Beck J, Kolson DL, JordanSciutto KL (2011) Site-specific hyperphosphorylation of $\mathrm{pRb}$ in HIV-induced neurotoxicity. Mol Cell Neurosci 47:154-165. CrossRef Medline

Anderson ER, Gendelman HE, Xiong H (2004) Memantine protects hippocampal neuronal function in murine human immunodeficiency virus type 1 encephalitis. J Neurosci 24:7194-7198. CrossRef Medline

Bae M, Patel N, Xu H, Lee M, Tominaga-Yamanaka K, Nath A, Geiger J, Gorospe M, Mattson MP, Haughey NJ (2014) Activation of TRPML1 clears intraneuronal $A \beta$ in preclinical models of HIV infection. J Neurosci 34:11485-11503. CrossRef Medline

Bernstein HG, Bukowska A, Krell D, Bogerts B, Ansorge S, Lendeckel U (2003) Comparative localization of ADAMs 10 and 15 in human cerebral cortex normal aging, alzheimer disease and down syndrome. J Neurocytol 32:153-160. CrossRef Medline

Borjabad A, Volsky DJ (2012) Common transcriptional signatures in brain tissue from patients with HIV-associated neurocognitive disorders, Alzheimer's disease, and multiple sclerosis. J Neuroimmune Pharmacol 7:914-926. CrossRef Medline

Brew BJ, Pemberton L, Blennow K, Wallin A, Hagberg L (2005) CSF amyloid beta42 and tau levels correlate with AIDS dementia complex. Neurology 65:1490-1492. CrossRef Medline

Brown LA, Jin J, Ferrell D, Sadic E, Obregon D, Smith AJ, Tan J, Giunta B (2014) Efavirenz promotes $\beta$-secretase expression and increased $\mathrm{A} \beta 1-$ 40,42 via oxidative stress and reduced microglial phagocytosis: implications for HIV associated neurocognitive disorders (HANDs). PLoS One 9:e95500. CrossRef Medline

Carvajal FJ, Mattison HA, Cerpa W (2016) Role of NMDA receptormediated glutamatergic signaling in chronic and acute neuropathologies. Neural Plast 2016:2701526. CrossRef Medline

Chang WP, Huang X, Downs D, Cirrito JR, Koelsch G, Holtzman DM, Ghosh AK, Tang J (2011) Beta-secretase inhibitor GRL-8234 rescues age-related cognitive decline in APP transgenic mice. FASEB J 25:775-784. CrossRef Medline

Chen W, Sulcove J, Frank I, Jaffer S, Ozdener H, Kolson DL (2002) Development of a human neuronal cell model for human immunodeficiency virus (HIV)-infected macrophage-induced neurotoxicity: apoptosis induced by HIV type 1 primary isolates and evidence for involvement of the bcl-2/Bcl-xL-sensitive intrinsic apoptosis pa. J Virol 76:9407-9419. CrossRef Medline

Chen X, Hui L, Geiger NH, Haughey NJ, Geiger JD (2013) Endolysosome involvement in HIV-1 transactivator protein-induced neuronal amyloid beta production. Neurobiol Aging 34:2370-2378. CrossRef Medline

Clifford DB, Fagan AM, Holtzman DM, Morris JC, Teshome M, Shah AR, Kauwe JS (2009) CSF biomarkers of alzheimer disease in HIV-associated neurologic disease. Neurology 73:1982-1987. CrossRef Medline

Colciaghi F, Borroni B, Pastorino L, Marcello E, Zimmermann M, Cattabeni F, Padovani A, Di Luca M (2002) [alpha]-Secretase ADAM10 as well as [alpha]APPs is reduced in platelets and CSF of Alzheimer disease patients. Mol Med 8:67-74. Medline

Cousins SL, Hoey SE, Anne Stephenson F, Perkinton MS (2009) Amyloid precursor protein 695 associates with assembled NR2A- and NR2Bcontaining NMDA receptors to result in the enhancement of their cell surface delivery. J Neurochem 111:1501-1513. CrossRef Medline

Cousins SL, Dai W, Stephenson FA (2015) APLP1 and APLP2, members of the APP family of proteins, behave similarly to APP in that they associate with NMDA receptors and enhance NMDA receptor surface expression. J Neurochem 133:879-885. CrossRef Medline

Cross SA, Cook DR, Chi AW, Vance PJ, Kolson LL, Wong BJ, Jordan-Sciutto KL, Kolson DL (2011) Dimethyl fumarate, an immune modulator and inducer of the antioxidant response, suppresses HIV replication and macrophage-mediated neurotoxicity: a novel candidate for HIV neuroprotection. J Immunol 187:5015-5025. CrossRef Medline

Dong Y, Tan J, Cui MZ, Zhao G, Mao G, Singh N, Xu X (2006) Calpain inhibitor MDL28170 modulates $A \beta$ formation by inhibiting the formation of intermediate $\mathrm{A} \beta 46$ and protecting $\mathrm{A} \beta$ from degradation. FASEB J 20:331-333. CrossRef Medline

Esiri MM, Biddolph SC, Morris CS (1998) Prevalence of alzheimer plaques in AIDS. J Neurol Neurosurg Psychiatry 65:29-33. CrossRef Medline

Fellgiebel A, Kojro E, Müller MJ, Scheurich A, Schmidt LG, Fahrenholz F (2009) CSF APPs $\alpha$ and phosphorylated tau protein levels in mild cognitive impairment and dementia of Alzheimer's type. J Geriatr Psychiatry Neurol 22:3-9. CrossRef Medline

Ferrarese C, Riva R, Dolara A, De Micheli A, Frattola L (1997) Elevated glutamate in the cerebrospinal fluid of patients with HIV dementia. JAMA 277:630. Medline

Ferrarese C, Aliprandi A, Tremolizzo L, Stanzani L, De Micheli A, Dolara A, Frattola L (2001) Increased glutamate in CSF and plasma of patients with HIV dementia. Neurology 57:671-675. CrossRef Medline

Fontana G, Valenti L, Raiteri M (1997) Gp120 can revert antagonism at the glycine site of NMDA receptors mediating GABA release from cultured hippocampal neurons. J Neurosci Res 49:732-738. CrossRef Medline

Gannon PJ, Akay-Espinoza C, Yee AC, Briand LA, Erickson MA, Gelman BB, Gao Y, Haughey NJ, Zink MC, Clements JE, Kim NS, Van De Walle G, Jensen BK, Vassar R, Pierce RC, Gill AJ, Kolson DL, Diehl JA, Mankowski JL, Jordan-Sciutto KL (2017) HIV protease inhibitors alter amyloid precursor protein processing via $\beta$-site amyloid precursor protein cleaving enzyme-1 translational up-regulation. Am J Pathol 187:91-109. CrossRef Medline

Gelman BB (2015) Neuropathology of HANDs with suppressive antiretroviral therapy: encephalitis and neurodegeneration reconsidered. Curr HIV/AIDS Rep 12:272-279. CrossRef Medline

Giulian D, Vaca K, Noonan CA (1990) Secretion of neurotoxins by mononuclear phagocytes infected with HIV-1. Science 250:1593-1596. CrossRef Medline

Green DA, Masliah E, Vinters HV, Beizai P, Moore DJ, Achim CL (2005) Brain deposition of beta-amyloid is a common pathologic feature in HIV positive patients. AIDS 19:407-411. CrossRef Medline

Gupta S, Knight AG, Gupta S, Knapp PE, Hauser KF, Keller JN, Bruce-Keller AJ (2010) HIV-tat elicits microglial glutamate release: role of NAPDH oxidase and the cystine-glutamate antiporter. Neurosci Lett 485:233-236. CrossRef Medline

Habib A, Sawmiller D, Tan J (2017) Restoring soluble amyloid precursor protein $\alpha$ functions as a potential treatment for Alzheimer's disease. J Neurosci Res 95:973-991. CrossRef Medline

Han P, Dou F, Li F, Zhang X, Zhang YW, Zheng H, Lipton SA, Xu H, Liao FF (2005) Suppression of cyclin-dependent kinase 5 activation by amyloid precursor protein: a novel excitoprotective mechanism involving modulation of tau phosphorylation. J Neurosci 25:11542-11552. CrossRef Medline

Harper SJ, Bilsland JG, Shearman MS, Zheng H, Van der Ploeg L, Sirinathsinghji DJ (1998) Mouse cortical neurones lacking APP show normal neurite outgrowth and survival responses in vitro. Neuroreport 9:3053-3058. CrossRef Medline

Hefter D, Draguhn A (2017) APP as a protective factor in acute neuronal insults. Front Mol Neurosci 10:22. CrossRef Medline

Hoe HS, Fu Z, Makarova A, Lee JY, Lu C, Feng L, Pajoohesh-Ganji A, Matsuoka Y, Hyman BT, Ehlers MD, Vicini S, Pak DT, Rebeck GW (2009) The effects of amyloid precursor protein on postsynaptic composition and activity. J Biol Chem 284:8495-8506. CrossRef Medline

Innocent N, Cousins SL, Stephenson FA (2012) NMDA receptor/amyloid precursor protein interactions: a comparison between wild-type and amyloid precursor protein mutations associated with familial Alzheimer's disease. Neurosci Lett 515:131-136. CrossRef Medline

Jiang ZG, Piggee C, Heyes MP, Murphy C, Quearry B, Bauer M, Zheng J, Gendelman HE, Markey SP (2001) Glutamate is a mediator of neurotoxicity in secretions of activated HIV-1-infected macrophages. J Neuroimmunol 117:97-107. CrossRef Medline

Johnston JA, Liu WW, Todd SA, Coulson DT, Murphy S, Irvine GB, Passmore AP (2005) Expression and activity of $\beta$-site amyloid precursor protein cleaving enzyme in Alzheimer's disease. Biochem Soc Trans 33: 1096-1100. CrossRef Medline

Kaul M (2008) HIV's double strike at the brain: neuronal toxicity and compromised neurogenesis. Front Biosci 13:2484-2494. Medline 
Kaul M, Garden GA, Lipton SA (2001) Pathways to neuronal injury and apoptosis in HIV-associated dementia. Nature 410:988-994. CrossRef Medline

Kayed R, Lasagna-Reeves CA (2013) Molecular mechanisms of amyloid oligomers toxicity. J Alzheimers Dis 33:S67-S78. CrossRef Medline

Kim DY, Carey BW, Wang H, Ingano LAM, Binshtok AM, Wertz MH, Pettingell WH, He P, Lee VM, Woolf CJ, Kovacs DM (2007) BACE1 regulates voltage-gated sodium channels and neuronal activity. Nat Cell Biol 9:755-764. CrossRef Medline

Kim J, Yoon JH, Kim YS (2013) HIV-1 Tat interacts with and regulates the localization and processing of amyloid precursor protein. PLoS One 8:e77972. CrossRef Medline

Kocahan S, Doğan Z (2017) Mechanisms of Alzheimer's disease pathogenesis and prevention: the brain, neural pathology, N-methyl-D-aspartate receptors, tau protein and other risk factors. Clin Psychopharmacol Neurosci 15:1-8. CrossRef Medline

Koenig S, Gendelman HE, Orenstein JM, Dal Canto MC, Pezeshkpour GH, Yungbluth M, Janotta F, Aksamit A, Martin MA, Fauci AS (1986) Detection of AIDS virus in macrophages in brain tissue from AIDS patients with encephalopathy. Science 233:1089-1093. CrossRef Medline

Lammich S, Kojro E, Postina R, Gilbert S, Pfeiffer R, Jasionowski M, Haass C, Fahrenholz F (1999) Constitutive and regulated alpha-secretase cleavage of Alzheimer's amyloid precursor protein by a disintegrin metalloprotease. Proc Natl Acad Sci U S A 96:3922-3927. CrossRef Medline

Lesné S, Ali C, Gabriel C, Croci N, MacKenzie ET, Glabe CG, Plotkine M, Marchand-Verrecchia C, Vivien D, Buisson A (2005) NMDA receptor activation inhibits $\alpha$-secretase and promotes neuronal amyloid- $\beta$ production. J Neurosci 25:9367-9377. CrossRef Medline

Levine AJ, Miller JA, Shapshak P, Gelman B, Singer EJ, Hinkin CH, Commins D, Morgello S, Grant I, Horvath S (2013) Systems analysis of human brain gene expression: mechanisms for HIV-associated neurocognitive impairment and common pathways with Alzheimer's disease. BMC Med Genomics 6:4. CrossRef Medline

Liang B, Duan BY, Zhou XP, Gong JX, Luo ZG (2010) Calpain activation promotes BACE1 expression, amyloid precursor protein processing, and amyloid plaque formation in a transgenic mouse model of Alzheimer disease. J Biol Chem 285:27737-27744. CrossRef Medline

Lindl KA, Akay C, Wang Y, White MG, Jordan-Sciutto KL (2007) Expression of the endoplasmic reticulum stress response marker, BiP, in the central nervous system of HIV-positive individuals. Neuropathol Appl Neurobiol 33:658-669. CrossRef Medline

Lipton SA, Rosenberg PA (1994) Excitatory amino acids as a final common pathway for neurologic disorders. N Engl J Med 330:613-622. CrossRef Medline

Lipton SA, Sucher NJ, Kaiser PK, Dreyer EB (1991) Synergistic effects of HIV coat protein and NMDA receptor-mediated neurotoxicity. Neuron 7:111-118. CrossRef Medline

MacLeod R, Hillert EK, Cameron RT, Baillie GS (2015) The role and therapeutic targeting of $\alpha$-, $\beta$ - and $\gamma$-secretase in Alzheimer's disease. Future Sci OA 1:FSO11. Medline

Masliah E, Roberts ES, Langford D, Everall I, Crews L, Adame A, Rockenstein E, Fox HS (2004) Patterns of gene dysregulation in the frontal cortex of patients with HIV encephalitis. J Neuroimmunol 157:163-175. CrossRef Medline

Mehta A, Prabhakar M, Kumar P, Deshmukh R, Sharma PL (2013) Excitotoxicity: bridge to various triggers in neurodegenerative disorders. Eur J Pharmacol 698:6-18. CrossRef Medline

Mitsuda N, Ohkubo N, Tamatani M, Lee YD, Taniguchi M, Namikawa K, Kiyama H, Yamaguchi A, Sato N, Sakata K, Ogihara T, Vitek MP, Tohyama M (2001) Activated cAMP-response element-binding protein regulates neuronal expression of presenilin-1. J Biol Chem 276:96889698. CrossRef Medline

Moidunny S, Matos M, Wesseling E, Banerjee S, Volsky DJ, Cunha RA, Agostinho P, Boddeke HW, Roy S (2016) Oncostatin M promotes excitotoxicity by inhibiting glutamate uptake in astrocytes: implications in HIV-associated neurotoxicity. J Neuroinflammation 13:144. CrossRef Medline

Mucke L, Abraham CR, Ruppe MD, Rockenstein EM, Toggas SM, Mallory M, Alford M, Masliah E (1995) Protection against HIV-1 gp120-induced brain damage by neuronal expression of human amyloid precursor protein. J Exp Med 181:1551-1556. CrossRef Medline
Munro KM, Nash A, Pigoni M, Lichtenthaler SF, Gunnersen JM (2016) Functions of the Alzheimer's disease protease BACE1 at the synapse in the central nervous system. J Mol Neurosci 60:305-315. CrossRef Medline

O'Connor T, Sadleir KR, Maus E, Velliquette RA, Zhao J, Cole SL, Eimer WA, Hitt B, Bembinster LA, Lammich S, Lichtenthaler SF, Hébert SS, De Strooper B, Haass C, Bennett DA, Vassar R (2008) Phosphorylation of the translation initiation factor eIF2alpha increases BACE1 levels and promotes amyloidogenesis. Neuron 60:988-1009. CrossRef Medline

O'Donnell LA, Agrawal A, Jordan-Sciutto KL, Dichter MA, Lynch DR, Kolson DL (2006) Human immunodeficiency virus (HIV)-induced neurotoxicity: roles for the NMDA receptor subtypes. J Neurosci 26:981-990. CrossRef Medline

Ohno M, Sametsky EA, Younkin LH, Oakley H, Younkin SG, Citron M, Vassar R, Disterhoft JF (2004) BACE1 deficiency rescues memory deficits and cholinergic dysfunction in a mouse model of Alzheimer's disease. Neuron 41:27-33. CrossRef Medline

Olsson A, Höglund K, Sjögren M, Andreasen N, Minthon L, Lannfelt L, Buerger K, Möller HJ, Hampel H, Davidsson P, Blennow K (2003) Measurement of alpha- and beta-secretase cleaved amyloid precursor protein in cerebrospinal fluid from alzheimer patients. Exp Neurol 183:74-80. CrossRef Medline

Ortega M, Ances BM (2014) Role of HIV in amyloid metabolism. J Neuroimmune Pharmacol 9:483-491. CrossRef Medline

Perez RG, Zheng H, Van der Ploeg LH, Koo EH (1997) The $\beta$-amyloid precursor protein of alzheimer's disease enhances neuron viability and modulates neuronal polarity. J Neurosci 17:9407-9414. Medline

Petito CK, Cho ES, Lemann W, Navia BA, Price RW (1986) Neuropathology of acquired immunodeficiency syndrome (AIDS): an autopsy review. J Neuropathol Exp Neurol 45:635-646. CrossRef Medline

Rempel HC, Pulliam L (2005) HIV-1 tat inhibits neprilysin and elevates amyloid beta. AIDS 19:127-135. CrossRef Medline

Sacktor N, Robertson K (2014) Evolving clinical phenotypes in HIVassociated neurocognitive disorders. Curr Opin HIV AIDS 9:517-520. CrossRef Medline

Sacktor N, Skolasky RL, Seaberg E, Munro C, Becker JT, Martin E, Ragin A, Levine A, Miller E (2016) Prevalence of HIV-associated neurocognitive disorders in the multicenter AIDS cohort study. Neurology 86:334-340. CrossRef Medline

Selkoe DJ, Wolfe MS (2000) In search of gamma-secretase: presenilin at the cutting edge. Proc Natl Acad Sci U S A 97:5690-5692. CrossRef Medline

Sengupta U, Nilson AN, Kayed R (2016) The role of amyloid- $\beta$ oligomers in toxicity, propagation, and immunotherapy. EBioMedicine 6:42-49. CrossRef Medline

Shin AH, Kim HJ, Thayer SA (2012) Subtype selective NMDA receptor antagonists induce recovery of synapses lost following exposure to HIV-1 tat. Br J Pharmacol 166:1002-1017. CrossRef Medline

Singer O, Marr RA, Rockenstein E, Crews L, Coufal NG, Gage FH, Verma IM, Masliah E (2005) Targeting BACE1 with siRNAs ameliorates Alzheimer disease neuropathology in a transgenic model. Nat Neurosci 8:13431349. CrossRef Medline

Soontornniyomkij V, Moore DJ, Gouaux B, Soontornniyomkij B, Tatro ET, Umlauf A, Masliah E, Levine AJ, Singer EJ, Vinters HV, Gelman BB, Morgello S, Cherner M, Grant I, Achim CL (2012) Cerebral $\beta$-amyloid deposition predicts HIV-associated neurocognitive disorders in APOE $\varepsilon 4$ carriers. AIDS 26:2327-2335. CrossRef Medline

Tong Y, Zhou W, Fung V, Christensen MA, Qing H, Sun X, Song W (2005) Oxidative stress potentiates BACE1 gene expression and Abeta generation. J Neural Transm 112:455-469. CrossRef Medline

Trojanowski JQ, Shin RW, Schmidt ML, Lee VM (1995) Relationship between plaques, tangles, and dystrophic processes in Alzheimer's disease. Neurobiol Aging 16:335-340. CrossRef Medline

Valcour VG (2013) HIV, aging, and cognition: emerging issues. Top Antivir Med 21:119-123. Medline

Verges DK, Restivo JL, Goebel WD, Holtzman DM, Cirrito JR (2011) Opposing synaptic regulation of amyloid- $\beta$ metabolism by NMDA receptors in vivo. J Neurosci 31:11328-11337. CrossRef Medline

White AR, Zheng H, Galatis D, Maher F, Hesse L, Multhaup G, Beyreuther K, Masters CL, Cappai R (1998) Survival of cultured neurons from amyloid precursor protein knock-out mice against Alzheimer's amyloid- $\beta$ toxicity and oxidative stress. J Neurosci 18:6207-6217 Medline 
White AR, Multhaup G, Maher F, Bellingham S, Camakaris J, Zheng H, Bush AI, Beyreuther K, Masters CL, Cappai R (1999) The Alzheimer's disease amyloid precursor protein modulates copper-induced toxicity and oxidative stress in primary neuronal cultures. J Neurosci 19:9170-9179. Medline

Wilcox KS, Buchhalter J, Dichter MA (1994) Properties of inhibitory and excitatory synapses between hippocampal neurons in very low density cultures. Synapse 18:128-151. CrossRef Medline

Xu J, Ikezu T (2009) The comorbidity of HIV-associated neurocognitive disorders and Alzheimer's disease: a foreseeable medical challenge in post-HAART era. J Neuroimmune Pharmacol 4:200-212. CrossRef Medline
Yang LB, Lindholm K, Yan R, Citron M, Xia W, Yang XL, Beach T, Sue L, Wong P, Price D, Li R, Shen Y (2003) Elevated $\beta$-secretase expression and enzymatic activity detected in sporadic alzheimer disease. Nat Med 9:3-4. CrossRef Medline

Zhou Y, Liu J, Xiong H (2017) HIV-1 glycoprotein 120 enhancement of $\mathrm{N}$-methyl-D-aspartate NMDA receptor-mediated excitatory postsynaptic currents: implications for HIV-1-associated neural injury. J Neuroimmune Pharmacol 12:314-326. CrossRef Medline

Zink WE, Anderson E, Boyle J, Hock L, Rodriguez-Sierra J, Xiong H, Gendelman HE, Persidsky Y (2002) Impaired spatial cognition and synaptic potentiation in a murine model of human immunodeficiency virus type 1 encephalitis. J Neurosci 22:2096-2105. Medline 